\author{
ANDRZEJ ANTONI SZCZEPANKIEWICZ \\ Pracownia Neuromorfologii Molekularnej i Systemowej \\ Pracownia Mikroskopii Elektronowej \\ Instytut Biologii Doświadczalnej im. M. Nenckiego PAN \\ Pasteura 3, 02-093 Warszawa \\ E-mail: a.szczepankiewicz@nencki.edu.pl
}

\title{
CETKI JĄDROWE JAKO MODELOWE CIAŁKA JĄDROWE. CĘTKI JĄDROWE W UKLADZIE NERWOWYM
}

\section{WSTEP: ARCHITEKTURA JĄDRA KOMÓRKOWEGO}

Jądra komórkowe pierwszy zaobserwował Antoni van Leeuwenhoek pod koniec XVII w. Od momentu kiedy ten holenderski przyrodnik zamieścił o nich wzmianke w jednym $z$ listów do Towarzystwa Królewskiego w Londynie (LEEUWENHOEK 1682), minęło prawie trzy stulecia nim zrozumiano jaka pełnia funkcję. Przechowywanie i kopiowanie informacji zawartej $\mathrm{w}$ materiale genetycznym oraz kontrolowanie prawie wszystkich funkcji komórki przez regulacje ekspresji tej informacji, możliwe jest dzięki złożonym molekularnym procesom powiazanym $z$ przestrzenna struktura jądra. Dzięki rozwojowi technik obrazowania mikroskopowego oraz technik biochemicznych poznano zróżnicowanie budowy wewnętrznej jądra na poziomie strukturalnym i procesów w nim zachodzacych na poziomie molekularnym. Jądro komórkowe bowiem, choć pozbawione wewnętrznych przedziałów błonowych, nie jest organella o jednorodnej organizacji. Elementy strukturalne jadra to chromatyna, czyli kompleks DNA i białek histonowych, oraz położone w przestrzeni międzychromatynowej, znacznie mniejsze struktury, zwane ciałkami jadrowymi (ang. nuclear bodies) lub domenami jądrowymi (ang. nuclear domains). Sa one kompleksami białek lub białek i niekodujacego RNA (BRASCH i OCHS 1992). Najbardziej wyrazistym i najwcześniej zauważonym, jest jąderko (WAGNER 1835). Niektóre ciałka jądrowe widoczne sa tylko $\mathrm{w}$ mikroskopii fluorescencyjnej po zastosowaniu specyficznego znakowania, inne $z$ kolei, dzięki charakterystycznej strukturze, maja swoje odpowiedniki na poziomie ultrastrukturalnym $\mathrm{w}$ mikroskopii elektronowej. Wyjatkowe jest tutaj właśnie jąderko, które dzięki dużej gęstości widoczne jest zarówno w zwykłym mikroskopie świetlnym, jak i elektronowym. Do tej pory opisano kilkanaście typów ciałek jadrowych. Nie wszystkie maja ustalone nazwy w języku polskim. Do ważniejszych należą: wspomniane już jąderko będące miejscem syntezy rRNA i niektórych etapów składania rybosomów, ciałka Cajala zaangażowane $\mathrm{w}$ pewne etapy modyfikacji i wewnatrzjadrowy transport małych jadrowych rybonukleoprotein (snRNPs) oraz małych jaderkowych rybonukleoprotein (snoRNPs)(MORRIS 2008, MACHYNA i współaut. 2013), ciałka PML uczestniczace $w$ odpowiedzi na czynniki stresowe, regulację stabilności genomu, naprawę DNA poprzez sekwestrację, modyfikowanie i degradację białkowych partnerów (LALLEMAND-BREITENBACH i DE THE 2010), ciałka Polycomb będace wielobiałkowym kompleksem, który u Drosophila zaangażowany jest $\mathrm{w}$ represje genów homeotycznych, a u ssaków w regulację ekspresji genów Hox (PIRROTTA i Li 2012), "cleavage bodies" zawierające kilka czynników uczestniczących w cięciu i poliadenylacji końca 3' mRNA (LI i współaut. 2006), jądrowe ciałka stresowe (ang. nuclear stress bodies) uczestniczące w regulacji i przeprogramowaniu transkrypcji w warunkach stresowych (BIAMONTI i VOURC'H 2010), „paraspeckles” biorace udział w regulacji ekspresji niektórych genów przez

Słowa kluczowe: ciałka jądrowe, cętki, dojrzewanie mRNA, jądro komórkowe, metabolizm mRNA, składanie mRNA, splicing, transkrypcja, transport mRNA 
retencje pewnych rodzajów RNA (Fox i LAMOND 2010, NAKAGAWA i HIROSE 2012) oraz „nuclear speckles” uważane za miejsce przechowywania i modyfikacji czynników składania mRNA: małych jadrowych rybonukleoprotein (snRNP), białek SR i innych białek metabolizmu RNA. Ta kompartmentalizacja przestrzeni jądra, tworzona przez ciałka jadrowe, umożliwia odpowiednia koncentrację makrocząstek, prowadząca do podwyższenia częstości koniecznych odziaływań między nimi $\mathrm{w}$ jednym miejscu i/lub obniżenia niepożądanych w innym (GALGANSKI i współaut. 2017). Ułatwia również sprawniejszą kontrolę ich retencji lub uwalniania do nukleoplazmy (HANDWERGER i GALL 2006).

\section{CETKI JADROWE: NAZEWNICTWO I POCZATTKI BADAN}

Obecnie w literaturze anglojęzycznej stosuje się równolegle kilka terminów na określenie cętek jądrowych. Najczęściej spotykany termin angielski „nuclear speckles” (nie majacy oficjalnego odpowiednika $\mathrm{w}$ jezyku polskim, a znaczacy mniej więcej tyle co plamki lub cetki jądrowe), używany jest głównie w kontekście obrazowania w mikroskopii immunofluorescencyjnej. „Interchromatin granule clusters" (IGCs) stosowany jest $\mathrm{w}$ badaniach mikroskopii elektronowej (SPECTOR i LAMOND 2011). Ten ostatni termin spotykany w literaturze polskojęzycznej, np. w pierwszej polskiej pracy przegladowej dotyczacej tych struktur (ZBOREK 1987), thumaczony jest jako skupiska ziaren interchromatynowych. Ponadto, w pracach prezentujacych wyniki immnofluorescencjne spotyka się, lecz znacznie rzadziej, inne, dodatkowe terminy: „splicing speckles”, „SC35 domains” oraz „splicing factor compartments” (GALGANSKI i współaut. 2017). To różne nazewnictwo w dwóch różnych typach mikroskopii wynika $\mathrm{z}$ niezależnego opisania tych struktur. W 1959 r. Hewson Swift zaobserwował $\mathrm{w}$ mikroskopie elektronowym ziarnistości, które w nukleoplazmie tworza skupiska („chmury”) i nazwał je ziarnami interchromatynowymi. Równocześnie stwierdził, że zawierają one RNA (SWIFT 1959). Następnie opisali je Nicole Granboulan i Wilhelm Bernhard (GRANBOULAN i BERNHARD 1961). Opracowana przez Bernharda metoda regresywnego barwienia $z$ użyciem EDTA, pozwalajaca zachować wysoki kontrast rybonukleoprotein przy wyblakłej chromatynie sugerowała, że ziarna interchoromatynowe zawieraja jakiś rodzaj rybonukleoprotein (MONNERON i BERNHARD 1969). Natomiast termin „speckles” został po raz pierwszy użyty przez J. Swensona Becka, który w 1961 r. opisał w hepatocytach szczurzych cętkowaty wzór barwienia jądra, po wyznakowaniu materiału surowica pochodzaca od pacjentów chorych na choroby autoimmunologiczne: zespół Sjögrena i toczeń rumieniowaty układowy (BECK 1961). Kilka lat później antygen odpowiedzialny za powstanie takiego wzoru barwienia został nazwany antygenem $\mathrm{Sm}$, od nazwiska pacjentki Stephanie Smith, chorej na toczeń rumieniowaty układowy, u której również zostały wykryte przeciwciała przeciwjadrowe (TAN 1967, TAN i KUnKel 1966). Produkcja tego typu przeciwciał jest charakterystyczną cechą chorób autoimmunologicznych, co bywa wykorzystywane $\mathrm{w}$ ich diagnostyce (KUMAR i współaut. 2009). Jednak dopiero w 1979 r. potwierdzono, że antygen Sm jest częścia kompleksu cząstek snRNP (LERNER i STEITZ 1979). Na poczatku lat 80. pojawily się pierwsze prace lokalizujące snRNP na poziomie ultrastrukturalnym, $z$ wykorzystaniem specyficznych przeciwciał (metoda immunogold) w IGC (SPECTOR i współaut. 1983, FAKAN i współaut. 1984, PUVION i współaut. 1984). Od tego momentu stało się oczywistym, że speckles i skupiska ziaren interchromatynowych to te same struktury, choć jeszcze przez wiele lat autorzy niechętnie stawiali obie nazwy obok siebie. Jednak, tak naprawdę, pierwszy opisał speckles już w 1910 r. Santiago Ramón y Cajal, hiszpański neurobiolog, laureat Nagrody Nobla $z$ 1906 r., odkrywca wspomnianych wcześniej ciałek Cajala. Ramón y Cajal wykazał w jadrze komórkowym neuronów obecność nieregularnych struktur, które nie barwia się kwaśna anilina i pozostaja jaśniejsze w stosunku do otoczenia, stąd użyta przez Ramona y Cajala nazwa grumos hialinos („prze-

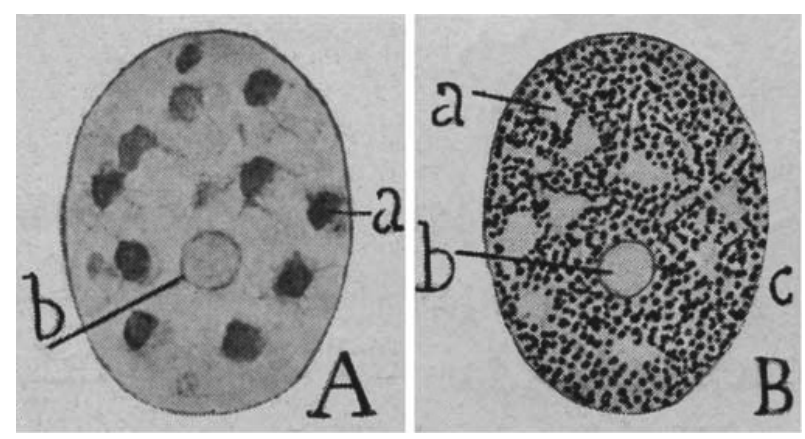

Ryc. 1. „Prześwitujące skupiska” (hiszp. grumos hialinos) czyli cętki w komórkach piramidalnych kory mózgowej królika.

Oryginalny rysunek wykonany przez Romóna y Cajala. A: cętki (a) oraz jąderko (b) uwidocznione metoda $z$ wykorzystaniem azotanu srebra po utrwaleniu w formalinie i moczniku. B: Negatywne barwienie cętek (a) i jąderka (b) azotanem srebra po utrwaleniu w formalinie i kwasie octowym. Pozytywnie barwia się "ziarna neutrofilów" (hiszp. granos netrófilos) (c). Reprodukowane $\mathrm{z}$ CAJAL (1910). 
świtujące skupiska”) (CAJAL 1910). Użycie przez tego badacza opracowanej przez siebie wcześniej metody barwienia azotanem srebra, pozwoliło selektywnie wyznakować opisane struktury (Ryc. 1). Późniejsza adaptacja tej metody do mikroskopii elektronowej potwierdziła, że obserwowane przez Ramona y Cajala struktury sa ekwiwalentem skupisk ziaren interchromatynowych, a tym samym speckles obserwowanych w mikroskopii immunofluorescencyjnej (LAFARGA i współaut. 2009). Ani J. Swenson Beck, ani tym bardziej Hewson Swift nie wiedzieli, że przedstawiaja struktury opisane wcześniej przez Ramóna y Cajala. Uważanie Ramóna y Cajala za odkrywcę nuclear speckles jest obecnie powszechne, choć gdy sięgnać do oryginalnego tekstu, Cajal wspomina, że struktury te były obserwowane także przez innych autorów (nie podaje przez kogo), choć nie poświęcono im większej uwagi (CAJAL 1910).

Mimo tylu lat opisywania w literaturze naukowej, struktury te nie doczekały się jeszcze polskiej nazwy, gdy chodzi o badania immunofluorescencyjne. Wspomniana, jedyna praca przeglądowa w języku polskim z 1987 r., odnosi się jedynie do badań w mikroskopii elektronowej i posługuje się terminem „ziarnistości interchromatynowe” (ZBOREK 1987). Termin „domeny SC35” jest wygodny, lecz dość nieścisły, gdyż struktury te zawieraja wiele innych białek. $Z$ kolei nazwa „kompartmenty czynników składania mRNA" (ang. splicing factor compartments) wydaje się zbyt długa i niezgrabna. Istnieje więc potrzeba utworzenia odpowiedniej polskiej nazwy. Dlatego, w niniejszej pracy, proponuje termin "cętki jądrowe", będacy właściwie dosłownym tłumaczeniem angielskiego terminu nuclear speckles, i taki termin będzie używany w poniższym tekście. Analogicznie w przypadku paraspeckles używany będzie termin „paracętki”. W miejscu, w którym będa omawiane wyniki prac mikroskopii elektronowej zostanie użyty termin IGC/cętki.

\section{ORGANIZACJA I LOKALIZACJA CETEK JĄDROWYCH}

Cętki obserwowane w mikroskopie fluorescencyjnym maja kształt mniej lub bardziej regularnych plamek o średnicy 0,5-3 $\mu \mathrm{m}$, położonych $\mathrm{w}$ przestrzeni miedzychromatynowej (Ryc. 2). W jednym jądrze może być ich zwykle od 10 do 50 , gdzie zajmuja 5-10\% objętości nukleoplazmy.

W mikroskopii elektronowej, jak już wspomniałem, odpowiednikiem cętek sa skupiska ziaren interchromatynowych (IGC). Tworza je 20-25 nanometrowej średnicy elektronowo gęste ziarna połączone cienkimi

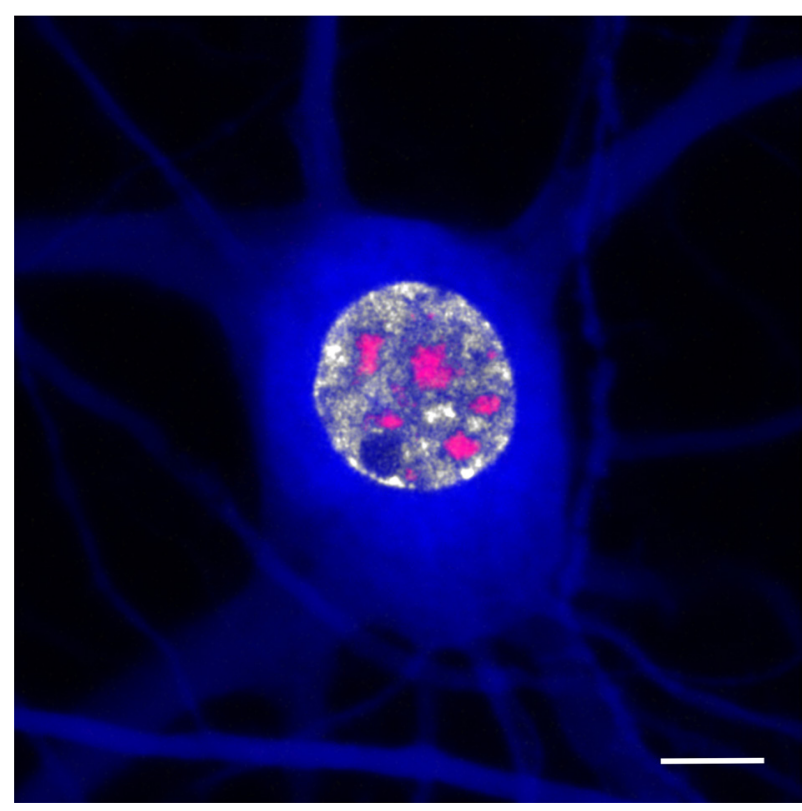

Ryc. 2. Cętki w mikroskopii fluorescencyjnej, w neuronach hodowli pierwotnej pochodzenia hipokampalnego (kolor czerwony).

$\mathrm{Na}$ niebiesko wybarwiono specyficzne dla neuronów białko MAP2, wykorzystywane jako ich znacznik. Na szaro wyznakowano DNA. Znacznik skali $6 \mu \mathrm{m}$. Z badań własnych autora.

włókienkami. Jedno takie skupisko odpowiada jednej "cętce" w mikroskopii świetlnej (Ryc. 3) (GALGANSKI i współaut. 2017, SPECTOR i LAMOND 2011, HALL i współaut. 2006). Ze względu na charakterystyczną strukturę, IGC/cętki moga być obserwowane bez użycia przeciwciał, choć korzystne jest zastosowanie technik zwiększajacych ich kontrast względem innych składników jądra, np. barwienie bizmutem, zastosowane po raz pierwszy przez LOCKEA i HUIEA (1977), lub zmniejszających kontrast heterochromatyny, jak wspominana wcześniej technika regresywnego barwienia EDTA (BERNHARD 1969).

Większość prac badających cętki dotyczy komórek ssaczych, jednak podobne struktury obserwowano w oocytach płazów, gdzie nazywane sa snurposomami B (GALL i współaut. 1999) i w embrionach Drosophila melanogaster (SEGALAT i LEPESANT 1992), lecz nie u drożdży (PotAshKin i współaut. 1990). Cętki występuja także w jądrach komórek roślinnych i były badane m.in. u Arabidopsis thaliana (FANG i współaut. 2004), Allium cepa i Lupinus luteus (NIEDOJADLO i współaut. 2012).

\section{BIAŁKOWE SKŁADNIKI CETEK JĄDROWYCH}

Metodami immunolokalizacji oraz spektrometria mas izolowanych frakcji IGC/cętek 

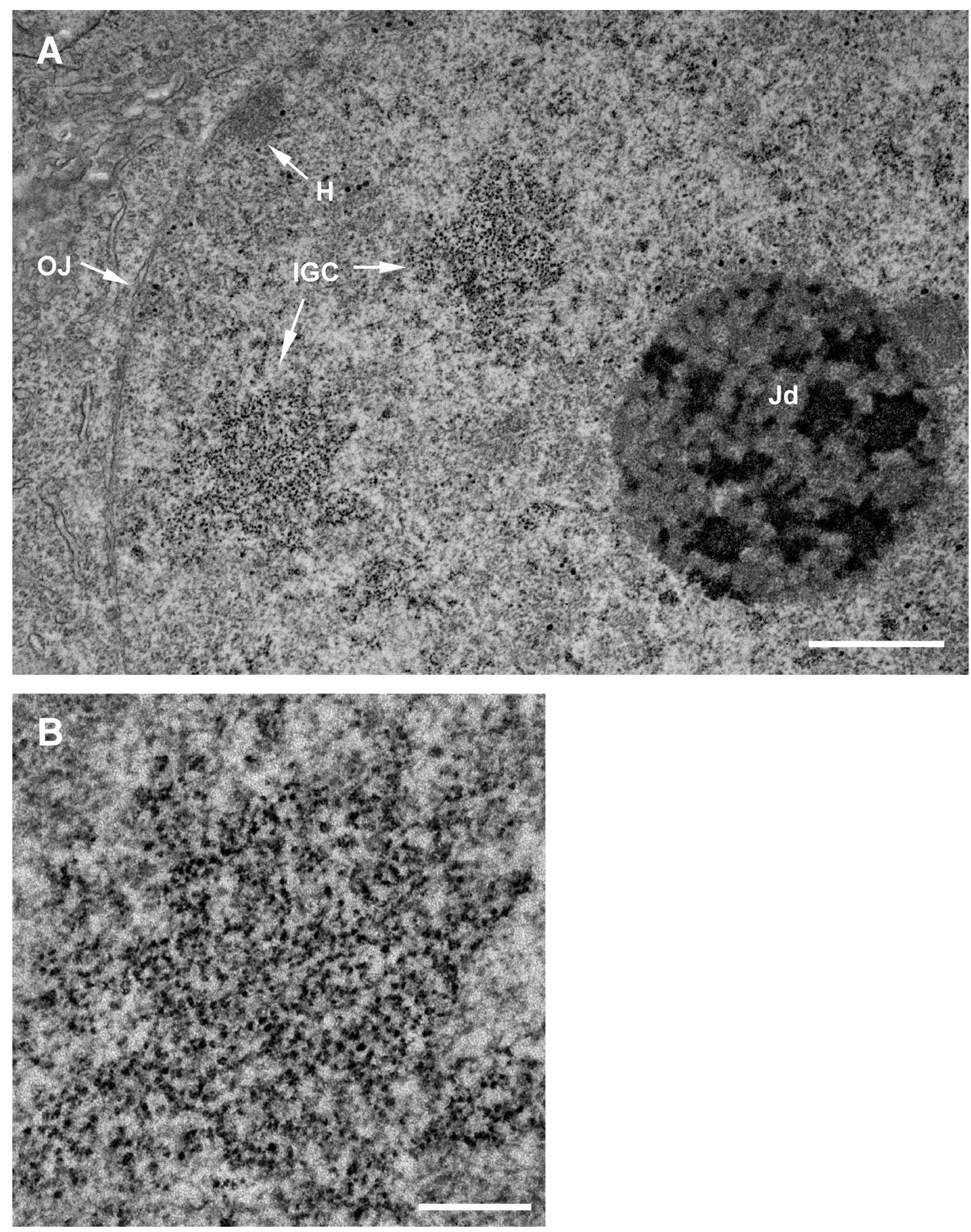

Ryc. 3. Skupiska ziaren interchromatynowych tj. cętek w mikroskopii elektronowej w komórkach nerwowych hipokampalnej hodowli organotypowej.

A: mikrofotografia elektronowa fragmentu jądra komórki nerwowej. $\mathrm{H}$ - heterochromatyna, IGC - skupiska ziaren interchromatynowych (ang. interchromatin granule clusters), OJ - otoczka jądrowa, Jd - jąderko. Znacznik skali $1 \mu \mathrm{m}$. B: jedno z IGC z Ryc. 3A w większym powiększeniu. Znacznik skali $330 \mathrm{~nm}$. Kontrast IGC wzmocniony solami bizmutu. $Z$ badań własnych autora. 
ustalono względnie dokładnie skład białkowy tych ciałek w hepatocytach. Podstawowym ich składnikiem sa dwie grupy czynników uczestniczacych w składaniu (splicingu) mRNA: małe jądrowe rybonukleoproteiny (ang. small nuclear rybonucleoprotein, snRNP) oraz białka SR (ang. serine-arginine rich proteins). Jako pierwsze w cętkach opisane zostały czynniki snRNP (por. rozdział "Cętki jądrowe: nazewnictwo i poczattki badań”). Czynniki te wchodza w skład spliceosomu, czyli wieloskładnikowego kompleksu białkowo-rybonukleoproteinowego, usuwającego introny podczas składania mRNA. Każda cząstka snRNP jest kompleksem składającym się $z$ snRNA, czyli niskoczasteczkowego RNA charakteryzującego się wysoka zawartościa grup urydylowych, wspólnego zestawu siedmiu tzw. białek rdzeniowych zwanych kompleksem Sm (B/B', D3, D2, $\mathrm{D} 1, \mathrm{E}, \mathrm{F}$ oraz $\mathrm{G})$ oraz białek unikatowych dla poszczególnych cząstek. Występuja cztery podstawowe rodzaje snRNP: U1, U2, U4/ U6 i U5 snRNP. Wszystkie rybonukleoproteiny snRNP oraz wszystkie białka $\mathrm{Sm}$, a także wiele spośród białek unikatowych sa wykrywane w obrębie cętek jądrowych (NYMAN i współaut. 1986, SAITOH i współaut. 2004). W ich biogenezie, jak już nadmieniono wyżej, uczestniczą ciałka Cajala (KIss 2004).

Druga ważna grupa białek obecną w cętkach sa białka SR. Jest to rodzina białek bogata w serynowo-argininowe powtórzenia, stąd nazwa (S to skrót aminokwasu seryny, $\mathrm{R}$ argininy). Białka SR na końcu aminowym maja jedną lub dwie domeny wiążace RNA: RRM (ang. RNA recognition motif) oraz nieco odmienna domenę homologiczna RRMH (ang. RRM homolog), natomiast na końcu karboksylowym różnej długości domenę RS z wielokrotnymi dwupeptydowymi powtórzeniami arginina-seryna. Domena ta, podlegajaca fosforylacji na resztach seryny, odpowiedzialna jest za interakcje $z$ innymi białkami, w tym $z$ transportyną-SR przenoszaca białka SR przez pory jadrowe. Znanych jest siedem klasycznych białek SR oraz kilkanaście dodatkowych, szczegółowo przedstawionych w kilku pracach przeglądowych (LONG i CACERES 2009, SHEPARD i HERTEL 2009, TWYFFELS i współaut. 2011). Wszystkie klasyczne oraz spora część dodatkowych wykrywana jest w cętkach hepatocytów (SAITOH i współaut. 2004). Za lokalizacje białek SR w cętkach odpowiada domena RS (CACERES i współaut. 1997). Białka SR pełnią funkcję czynników regulatorowych w konstytutywnym i alternatywnym składaniu mRNA: rozpoznaja regulatorowe sekwencje wzmacniajace ESEs (ang. exonic splicing enhancers) i wiążą się z nimi, przez co promują rekrutację komponentów spliceosomu w miejsca składa- nia. Jednak funkcje białek SR nie ograniczaja się tylko do kontrolowania składania mRNA. Białka te maja swój udział także w poprzedzajacej składanie transkrypcji, a także w eksporcie mRNA do cytoplazmy oraz w translacji (LONG i CACERES 2009). Dwa najlepiej poznane białka tego typu obecne w cetkach to SF2/ASF (ang. splicing factor 2/ alternative splicing factor) i SC35 (ang. spliceosomal component 35), według nowszej nomenklatury, próbujacej ujednolicić nazewnictwo w tej grupie białek, nazywane sa odpowiednio: SRSF1 i SRSF2 (ang. serine/ arginine-rich splicing factor). Białko SC35 (SRSF2) jest powszechnie uznawanym (ale nie jednym) znacznikiem cętek w różnych technikach obrazowania.

Cętki jądrowe zawierają niektóre $z$ tzw. białek podobnych do białek SR (ang. SR-like lub SR-related protein). Sa to białka, które także pełnią funkcje czynników składania pre-mRNA lub uczestnicza w innych procesach metabolizmu mRNA, ale maja pewne odmienne cechy budowy, np. brak u nich domeny RRM (LONG i CACERES 2009). W cętkach zlokalizowano także kilka kinaz i fosfataz, które fosforyluja lub defosforyluja czynniki uczestniczące w składaniu RNA, np. specyficzne dla jąder: CLK1 (ang. CDC-like kinase 1), PRP4K (ang. serine/threonine-protein kinase PRP4 homolog) oraz obecne również w PSK-H1 (ang. protein serine kinase H1), SRPK1 (ang. SRSF protein kinase 1) (COLWILl i współaut. 1996, Ko i współaut. 2001, BREDE i współaut. 2002, DELlAIRE i współaut. 2002) i fosfatazę PP1 (ang. protein phosphatase-1) (TRINKLE-MULCAHY 1999).

Ponadto wykazano w cętkach obecność wielu białek zwiazanych $z$ innymi etapami metabolizmu mRNA, w tym $z$ sama transkrypcja. Oprócz kilku czynników transkrypcyjnych (FBI-1, Skip, Tho2), ciałka te zawieraja dużą podjednostkę polimerazy RNAII (BREGMAN i współaut. 1995, MORTILLARO 1996, XIE i współaut. 2006), a także inne podjednostki jej kompleksu (SAITOH i współaut. 2004). Ponadto w cętkach znaleziono: czynniki dojrzewania końca 3' RNA jak PABPN1 (KRAUSE i współaut. 1994) oraz polimerazę PAP (ScHUL i współaut. 1998), białka uczestniczace $\mathrm{w}$ metylacji reszt A mRNA w pozycji N6, tj. METTL14 i METTL3 (PING i współaut. 2014), białka zaangażowane w transport mRNA do cytoplazmy: Aly/ REF i NXF1 (ZHOU i współaut. 2000), białka uczestniczace w procesie NMD (ang. nonsense-mediated mRNA decay), tj. degradacji wadliwych mRNA niosacych przedwczesny kodon stop jak Magoh i Y14. Dwie ostatnie grupy białek sa częścia EJC (ang. exon junction complex), białkowego kompleksu formujacego się na mRNA podczas skła- 


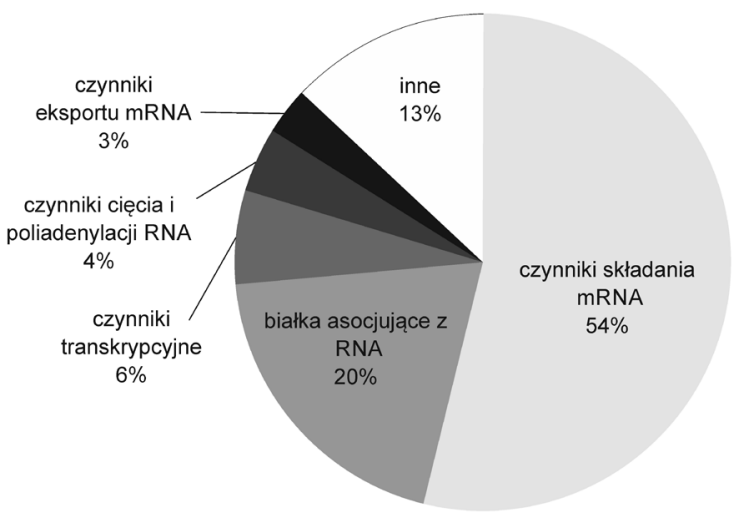

Ryc. 4. Klasyfikacja funkcji molekularnych białek obecnych w cętkach jądrowych.

IGC/cętki izolowane $z$ mysich hepatocytów. Wykres sporządzono na podstawie 146 białek zidentyfikowanych przy wykorzystaniu spektometrii mas przez SAITOH i współaut. (2004).

dania, majacego wpływ na potranskrypcyjna regulację jego losów (LE HIR i współaut. 2001, SCHMIDT i współaut. 2006).

W cętkach stwierdzono również obecność wielu rodzajów białek $z$ grupy hnRNP (ang. heterogeneous nuclear ribonucleoproteins, heterogenne jadrowe RNP) (SAITOH i współaut. 2004). Jest to duża rodzina białek wiażacych RNA. Białka te (wraz z czynnikami opisanymi wcześniej) uczestniczą w regulacji transkrypcji, alternatywnym składaniu mRNA, odpowiadaja za stabilizację mRNA i jego transport (GEUENS i współaut. 2016). Jednocześnie, w cętkach wykazano obecność białek cytoszkieletu: aktyny (NAKAYASU i UEDA 1984, BELIN i współaut. 2013), profiliny (SKARE i współaut. 2003) i laminy A/C (JAGATHEESAN 1999).

Niektóre białka obecne w cętkach występuja również $\mathrm{w}$ innych ciałkach. snRNAP sa składane $\mathrm{w}$ ciałkach Cajala zanim trafia do cętek (MAO i współaut. 2011b). Charakterystyczne białka paracętek: PSF i PSP2, występuja również w cętkach (SAITOH i współaut. 2004), a Pat1b w cettkach i ciałkach PML (MARNEF i współaut. 2012).

Proteomiczna analiza jadrowej frakcji bogatej $\mathrm{w}$ cętki, izolowanej $\mathrm{z}$ hepatocytów, o której wspominałem na poczatku tego rozdziału, wykazała występowanie w cętkach 360 białek, w tym 146 (41\%), które określono jako „Zidentyfikowane” białka IGC. Zaliczono tutaj białka najczęściej się pojawiajace, o wcześniej potwierdzonej lokalizacji w cętkach i o funkcji zbliżonej do funkcji dobrze scharakteryzowanych białek cettek. Pozostałe stanowiły „potencjalne” białka IGC, a także białka, które określono jako „nowi kandydaci” oraz białka „nieoczekiwane”, bę- dące być może zanieczyszczeniem frakcji. Rycina 4 prezentuje funkcje tych 146 zidentyfikowanych białek: $81 \% \mathrm{z}$ nich powiazanych jest $z$ metabolizmem pre-mRNA/mRNA i w dużej części pokrywa się z białkami znajdowanymi w spliceosomach (SAITOH i współaut. 2004). Najnowsza praca przegladowa podaje listę 457 znanych białek obecnych w cętkach (GALGANSKI i współaut. 2017).

\section{RNA W CETKACH JADROWYCH}

Prócz białek, cętki jądrowe zawierają dwa typy RNA: poli(A) ${ }^{+}$RNA (CARTER i współaut. 1991) oraz MALAT1 (ang. metastasis associated lung adenocarcinoma transcript 1), nazywany też NEAT2 (ang. nuclear-enriched abundant transcript 2), należacy do grupy długich niekodujacych RNA (lncRNAs, ang. long non-coding RNAs) (HUTCHINSON i współaut. 2007). Przez wiele lat kwestia dyskusyjna było czy obecne w cętkach poli(A) ${ }^{+}$RNA reprezentuje nowopowstałe mRNA (jako, że fragment poli(A) ${ }^{+}$RNA jest dodawany do końca 3' w procesie jego dojrzewania), czy też jest odrębna populacja niekodującego RNA. Niektóre prace pokazuja, że poli(A) ${ }^{+}$ RNA pozostaje w cętkach po zablokowaniu transkrypcji, pomimo że mRNA jest $\mathrm{w}$ tym czasie transportowane do cytoplazmy. Na tej podstawie wnioskowano, że cętki zawieraja stabilna populację poli(A) ${ }^{+}$RNA która być może pełni jakieś funkcje regulatorowe $\mathrm{w}$ jadrze (HuANG i współaut. 1994).

MALAT1 o długości około 7500 par zasad posiada krótki fragment podobny do poli(A), wchodzacy w skład konserwatywnej potrójnej helisy stabilizujacej transkrypt. MALAT1 ulega silnej nadekspresji $\mathrm{w}$ pewnych typach nowotworów (Ji i współaut. 2003). Doświadczenia na liniach komórkowych wykazały, że MALAT1 oddziałuje $z$ kilkoma białkami SR (m.in. SRSF1, SRSF2 i SRSF3) i jest potrzebny do ich lokalizacji w cętkach (TRIPATHI i współaut. 2010), a także $z$ innymi białkami cętek: RNPS1, SRm160 oraz IBP160, od których z kolei zależy lokalizacja MALAT1 w cętkach (MIYAGAWA i współaut. 2012). W hodowlach mysich neuronów hipokampalnych, MALAT1 moduluje synaptogeneze poprzez regulację ekspresji genów (BERNARD i współaut. 2010). Jaadra komórek niektórych linii nowotworowych po deplecji MALAT1 zawieraja zwiększony poziom defosforylowanych białek SR, które jednocześnie wykazuja bardziej homogenna dystrybucje w nukleoplazmie (TRIPATHI i współaut. 2010). Jednak badania in vivo, na myszach pozbawianych genu Malat1 wykazały, że transkrypt MALAT1 nie jest konieczny $w$ ich pre- i postnatalnym rozwoju. Myszy te posiadaja typowe cętki jądrowe, a brak MALAT1 nie wpływa 
na wzór jądrowej lokalizacji białek SRSF1 i SRSF2, poziom fosforylacji białek SR, proliferację komórek, apoptozę, ogólny poziom transkrypcji czy tempo składania mRNA. Jedynym obserwowanym efektem jest zmiana poziomu ekspresji kilku genów położonych w pobliżu Malat1, w tym genu Neat1, którego transkrypt jest składnikiem paracętek. O ile jednak niektórzy badacze obserwuja zwiększona ekspresję transkryptu Neat1 w korze mózgowej i wątrobie myszy $z$ wyciszonym genem Malat1 (ZHANG i współaut. 2012), inni zauważaja zmniejszona jego ekspresję w nabłonku jelita i fibroblastach (NAKAGAWA i współaut. 2012).

Białka i RNA w cętkach nie sa rozmieszczone homogennie, ale tworza dwie warstwy: środek cętek zajmowany jest częściej przez białka, a MALAT1 i niektóre rybonukleoproteiny występuja bardziej na zewnatrz (FEI i współaut. 2017). Granice pomiędzy tymi warstwami nie sa jednak ostre $i$ w strukturze obserwowanej w mikroskopii elektronowej to zróżnicowanie nie jest widoczne (Ryc. 3).

\section{FOSFOLIPIDY INOZYTOLOWE W CETTKACH JĄDROWYCH}

Pochodne fosfoinozytydów (PI), będace czynnikami sygnałowymi wielu cytoplazmatycznych szlaków, obecne sa także w jądrze komórkowym, gdzie uczestniczą w procesach regulacji modyfikacji chromatyny, dojrzewania mRNA i jego eksporcie. BORONENKOV i współaut. (1998) wykazali obecność w cętkach jądrowych fosfatydyloinozytolów bisfosforanu (PIP2) oraz dwu kinaz: fosfatydylo-4-fosforanu 5 typu I i typu II odpowiedzialnych za ich metabolizm. Obecnie znanych jest ponad 20 białek uczestniczacych w sygnalizacji $z$ udziałem PI, których obecność stwierdza się w cętkach (GALGANSKI i współaut. 2017). Przykładem może być „niekanoniczna” polimeraza Star-PAP (ang. speckle targeted PIP5K1a-regulated poly(A) polymerase), przeprowadzająca poliadenylację końca 3' specyficznego zbioru pre-mRNA w sposób zależny od PI (MELLMAN i współaut. 2008). Te i inne okoliczności zawarte w pracy przeglądowej GALGANSKIEGO i współaut. (2017) dowodzą zdaniem autorów, że cętki sa jadrowym centrum wytwarzania i transdukcji sygnału $z$ udziałem PI.

\section{FORMOWANIE SIE CETEK I MOBILNOSC ICH SKŁADNIKÓW}

Obecnie uważa się, że jądrowe i cytoplazmatyczne ciałka pozbawione błon oddzielajacych je od otoczenia, swym zachowaniem i struktura przypominaja krople płynu zawie- szone w innym roztworze. Ich powstawanie ma być oparte na zjawisku separacji faz w układzie dwu cieczy (ang. liquid-liquid phase separation, LLPS). LLPS jest procesem, w którym roztwory spontanicznie rozdzielaja się na niezmieszane fazy zawieszone jedna w drugiej. W przypadku ciałek obecnych w komórkach, jedna ciecz stanowi cytoplazma lub nukleoplazma, a druga skoncentrowana „zawiesina” białek lub białek i RNA. Rozdzielanie się jest wynikiem wielowartościowych (wielopunktowych), przejściowych odziaływań białko-białko i białko-RNA. Biora w nich udział specyficzne domeny białek ułatwiających czy wręcz promujących agregację tzw. domeny inherentnie nieuporządkowane (ang. intrinsically disordered regions), będace rejonami pozbawionymi struktury trzeciorzędowej, a więc nieulegające zwijaniu i nie przyjmujace form globularnych, najczęściej w wyniku braku hydrofobowych aminokwasów. Rodzajem tych domen sa low-complexity regions, czyli regiony o niskiej złożoności, które w białkach obecnych w cętkach i innych ciałkach, występuja wyjątkowo często. Sa to rejony, które zawieraja nadreprezentację jakiegoś konkretnego zestawu aminokwasów w strukturze pierwszorzędowej. Taka definicję niewatpliwe spełniaja białka SR $z$ domena RRM oraz RS i tak też zostały one sklasyfikowane (VAN DER LEE i współaut. 2014). Kiedy lokalne stężenie tego typu białek lub białek i specyficznego RNA osiagnie odpowiedni próg, zainicjowane zostaje gromadzenie się tych molekuł (zgodnie $z$ fizyko-chemia zjawiska LLPS) w większe struktury, tworzace ciałka. Zjawisko LLPS, w kontekście organelli pozbawionych błony jądrowej, zostało wyczerpujaco opisane w kilku pracach przeglądowych (HYMAN i współaut. 2014, COURCHAINE i współaut. 2016, SAWYER i współaut. 2019).

"Płynne" cętki sa strukturami dynamicznymi, ich rozmiar, kształt i liczba moga się zmieniać w zależności od typu komórki, cyklu komórkowego, poziomu ekspresji genów czy nasilenia procesu składania mRNA, a ich składniki sa w ciagłym ruchu (PHAIR i Misteli 2000). Małe cętki moga ulegać fuzji z większymi (ZHANG i współaut. 2016). Analiza ruchu cętek w komórkach CHO (ang. Chinese hamster ovary cell, komórki jajnika chomika chińskiego) pokazuje, że po zablokowaniu transkrypcji wzrasta mobilność cętek: przemieszaja się jedne w kierunku drugich na dystansie do $4 \mu \mathrm{m}$ i $z$ prędkością 0,2-1,5 $\mathrm{\mu m} / \mathrm{min}$, co kończy się ich połączeniem. Trzy lub cztery cętki moga poruszać się tą samą ścieżka, a na tej ścieżce moga powstawać nowe cętki podażajace za poprzednimi. Ruchy te sa niezależne od aktyny i odbywaja się „kanałami” wolnymi od 
chromatyny, a bogatymi w składniki obecne $\mathrm{w}$ cetkach. Podobne przemieszczanie się całych cętek, autorzy obserwuja po zastosowaniu szoku cieplnego, metali ciężkich i podczas później fazy G2 i wczesnej profazy (KIM i współaut. 2019). Te ostatnie badania potwierdzaja starsze obserwacje pokazujące, że zablokowanie transkrypcji $\mathrm{w}$ wyniku użycia specyficznych inhibitorów, np. a-amanityny (HUANG i współaut. 1994), lub w wyniku szoku cieplnego (SPECTOR i współaut. 1991), powoduje akumulację czynników składania mRNA w cetkach, co $z$ kolei prowadzi do ich powiększania się i przyjmowania bardziej zaokraglonych i wyraźniejszych granic. Podobny efekt obserwowano po zablokowaniu składania pre-mRNA, w następstwie mikroiniekcji oligonukleotydów blokujących niektóre U snRNA (O'KEEFE i wspólaut. 1994) oraz przy użyciu inhibitora spliceostatyny A. Powiększone cętki zawieraja nie tylko zwiększona liczbę czynników uczestniczących w składaniu mRNA, ale również poli(A) ${ }^{+}$RNA oraz białko PABPN1 (KAIDA i współaut. 2007, HETT i WEST 2014). Kiedy wzrasta ekspresja genów, a więc także roŝnie poziom składania mRNA, czynniki składania zgromadzone w cętkach sa uwalniane, zaś cętki przyjmują bardziej nieregularne kształty o słabiej zarysowanych granicach. Zjawisko takie obserwowano po indukcji określonych genów (HUANG i SPECTOR 1991), jak i grup genów w wyniku wywołanej infekcji wirusowej (BRIDGE 1995).

Ruch czynników składania mRNA $z$ i do cętek był badany przy zastosowaniu rożnych technik fluorescencyjnych. Wykorzystując białko fuzyjne GFP-SF2/ASF obserwowano redystrybucje czynników składania $z$ sassiednich cętek do miejsc transkrypcji aktywowanych genów, gdzie ma miejsce kotranskrypcyjne składanie mRNA (MISTELI i współaut. 1997). Z kolei użycie techniki FRAP (ang. fluorescence recovery after photobleaching) pokazało, że całkowite przywrócenie fluorescencji po fotoblaknięciu w przypadku białka GFP-AF2/ASF następuje po 30 sekundach, a połowiczne jest mniejsze niż 5 sekund. Maksymalny czas przebywania białka GFP-SF2/ASF w cętkach to około 50 sekund. Choć tempo wymiany składników cętek jest szybkie, rozmiar cętek podczas interfazy pozostaje względnie stały (PHAIR i MisTELI 2000).

Regulacja wymiany białkowych składników cętek następuje w głównej mierze na drodze fosforylacji i defosforylacji. Fosforylacja domeny RS jest konieczna do uwolnienia białek SR $z$ cętek $i$ ich przemieszczenia do miejsc transkrypcji i składania mRNA (MISTELI 1998) oraz formowania spliceosomu (Mermoud i współaut. 1994). Jak odno- towano wyżej, kilka kinaz, które mogą brać udział $\mathrm{w}$ tych procesach, zlokalizowano $\mathrm{w}$ cętkach. Nadekspresja kinazy CLK1 lub dodanie kinazy SRPK1 do permeabilizowanych komórek skutkuje ucieczka czynników składania mRNA $z$ cętek i zwiększeniem ich nukleplazmatycznej puli. Dotyczy to nie tylko białek SR fosforylowanych przez tę kinazę, ale także innych białkowych składników cętek nie posiadajacych domeny RS (np. komponentów U2 snRNP, pininy, aktyny i laminy A), a nawet populacji poli(A) ${ }^{+}$RNA (GUI i współaut. 1994, SACCO-BUBULYA i SPECTOR 2002). Nie tylko fosforylacja, ale także metylacja, koniugacja z PI (OKADA i współaut. 2008) czy z SUMO-1 (CHEN i współaut. 2004) sa modyfikacjami potranslacyjnymi, które reguluja napływ czynników do cętek.

\section{CETKI JADROWE W CYKLU KOMOORKOWYM I ICH BIOGENEZA}

Po wejściu komórki w mitozę i rozpadzie otoczki jądrowej, białka cętek ulegaja rozproszeniu w cytoplazmie. W metafazie białka te zaczynaja gromadzić się i tworzyć struktury nazwane mitotic interchromatin granules (MIGs), istniejące do telofazy i będace mitotycznym odpowiednikiem IGC/ cętek (FERREIRA i współaut. 1994, REUTER i współaut. 1985, LESER i współaut. 1989). $\mathrm{W}$ anafazie i wczesnej telofazie wzrasta wielkość i liczba MIGs, a podczas odbudowy otoczki jądrowej w środkowej i późnej telofazie czynniki składania mRNA zgromadzone w cytoplazmatycznych MIGs zaczynaja wnikać do tworzacych się jąder siostrzanych. Różne komponenty MIGs sa uwalniane w różnym czasie: białko ASF/SF2 i większość innych czynników opuszcza MIGs właśnie w telofazie, zaś białko SC35 i forma elongacyjna polimerazy II RNA fosforylowana na Ser-2 (także obecna w cętkach), pozostaja w nich do poczatku fazy G1 (forma inicjacyjna, fosforylowana na Ser-5, pojawia się w jądrach siostrzanych jako pierwsza, jeszcze przed czynnikami składania mRNA) (PRASANTH i współaut. 2003). Zanim jednak wnikające białka SR utworzą cętki, przez 15-20 min przejściowo przebywaja wokół transkrypcyjnie aktywnych organizatorów jaderka (ang. nucleolar organizing regions, NORs), gdzie tworza zagęszczony obszar nazwany przez odkrywców zjawiska NAPs (ang. NOR-associated patches) (BUBULYA i współaut. 2004). Z kolei snRNPs lokalizuja się w biegunowych rejonach jader siostrzanych razem z koilina p80, charakterystycznym białkiem ciałek Cajala. Białka SR w NAPS-ach sa hiperfosforylowane. W strukturach tych obecna jest także kinaza CLK1, a zablokowanie transkrypcji powoduje, że białka SR zostaja 
zatrzymane w NAPs-ach na dłużej. Oznacza to najprawdopodobniej, że fosforylacja uwalnia białka SR z NAPS-ów, zaś pierwszym miejscem docelowym, dokąd one zmierzaja i formuja pierwsze cętki, sa miejsca aktywne transkrypcyjnie (BuBULYA i współaut. 2004). Ponieważ zainicjowanie transkrypcji w telofazie poprzedza uformowanie się cętek, sugeruje się, że nabór czynników składania RNA do nowopowstałych transkryptów zapoczatkowuje zarodkowanie nowych cętek w pobliżu miejsc aktywnych transkrypcyjnie. Tezę tą wspiera fakt, że transkrypty mRNA w postaci eksperymentalnie wprowadzonych do jądra konstruktów, moga wywołać zarodkowanie cętek de novo (SHEVTSOV i DUNDR 2011).

\section{FUNKCJE CETEK JAADROWYCH; CETKI A GENY}

Początkowo cętki uznawano jedynie za miejsce magazynowania i modyfikacji czynników składania mRNA, $z$ których sa te czynniki wysyłane do miejsc, gdzie odbywa się transkrypcja i składania jej produktów. Za taka bierna rola cętek przemawia fakt, że na ich terenie nie jest wykrywalna transkrypcja metodami inkorporacji znakowanych nukleotydów (PUVION i PUVION-DUTILLEUL 1996, IBORRA i współaut. 1998, CMARKO 1999). Praca CMARKO (1999) sugeruje także, że nowopowstałe pre-mRNA obecne jest nie w obszarze cętek, ale we włóknach perychromatynowych, strukturach sassiadujacych $z$ cetkami, obserwowanymi w mikroskopie elektronowym. Jednak liczne późniejsze prace wskazują, że cętki moga wiązać się $z$ loci określonych aktywnych genów. W ludzkich fibroblastach, na obrzeżach cętek, pojawiaja się geny kolagenu Ia1 (COL1A1) i $\beta$-aktyny (ACTB), a we wnętrzu cętek transkrypty, tj. mRNA tych genów (XING i współaut. 1995). Umiejscawianiu się (asocjacji) $z$ cętkami ulegaja także aktywne geny: białek szoku cieplnego hsp90a i hsp70 ludzkich fibroblastów (Jolly i współaut. 1999), czynnika transkrypcyjnego E2F4 (EF2F4) i laminy A/C otoczki jądrowej (LMNA) (SMITH i współaut. 1999a), białka proteolipidowego (lipofiliny, PLP) w różnicujacych się oligodendrocytach (NIELSEN i współaut. 2002), łańcucha ciężkiego miozyny (MyHC) i miogeniny (Myf-4) ludzkich mioblastów (MOEN JR i współaut. 2004), receptora $Y$ aktywowanego przez proliferatory peroksysomów (PPARG), czynnika transkrypcyjnego SREBF1 oraz białka wiążącego kwasy tłuszczowe (FABP4) w różnicujacych się adipocytach (SzczERBAL i BRIDGER 2010). Wykazano także, że zestaw kilku jednocześnie aktywnych i funkcjonal- nie powiązanych genów może umiejscawiać się przy tej samej cętce, np. geny a-globiny $(H B A)$ i $\beta$-globiny $(H B B)$ (BROWN i współaut. 2006) czy a-globiny i białka prażka 3 błony erytrocytów (SLC4A1) podczas erytropoezy (w tym drugim przypadku obie kopie obydwu genów jednocześnie, Ryc. 5) (BROwN i współaut. 2008).

Rozpad cętek w wyniku nadekspresji kinazy CLK2 fosforylujacej białka SR, skutkuje znaczącym zmniejszeniem częstości występowania dwu genów (wiążących się $z$ tą sama cętka) w bliskim sąsiedztwie, co sugeruje, że obecność cętek promuje przestrzenna asocjację genów (RIEDER i współaut. 2014). DNA nie jest w cętkach wykrywalne (THIRY 1995), wykazano jednak, że cętki w mysich spermatydach zawieraja histon H2A.B.3, powiazany $z$ silnie rozluźniona chromatyna, a także obie formy polimerazy RNA II (fosforylowanej na Ser2 i Ser5), a modyfikacje chromatyny zwiazane $z$ jej aktywnościa (H4K20me1 i H3K36me3) występuja na obrzeżach lub we wnętrzu cętek (SOBOLEva i współaut. 2017). Regiony chromosomów bogate w geny (prażki R) odnajdywane sa w pobliżu cętek częściej niż regiony ubogie w geny (prażki G) (SHOPLAND i współaut. 2003). Umiejscawianie się genów przy cętkach nie jest jednak zjawiskiem masowym i obligatoryjnym, gdyż nie wszystkie geny, nawet te które podlegaja intensywnym procesom transkrypcji i składania, lokalizują się przy lub w cętkach (SMITH i współaut. 1999a). Dotyczy to raczej specyficznych genów, w specyficznych warunkach fizjologicznych. To ostatnie stwierdzenie nadal pozostaje aktualne, jednak w ostatnim czasie pojawiaja się prace mogace mu zaprzeczyć. Wielkoskalowe badania $z$ wykorzystaniem techniki SPRITE (ang. split-pool recognition of interactions by tag extension), dajace wgląd w przestrzenna organizację genomu dowodza, że rejony bogate w często transkrybowane geny $\mathrm{i}$ w modyfikacje chromatyny zwiazane $z$ aktywnościa transkrypcyjna, nazwane przez autorów active hub, lokalizują się w pobliżu cętek (QUINODOZ i współaut. 2018). Autorzy tej pracy konkludują, że lokalizacja DNA blisko cętek może zwiększać wydajność potranskrypcyjnej obróbki mRNA w wyniku dużej koncentracji czynników składania i metabolizmu mRNA. $Z$ kolei metoda TSA-Seq, wykorzystująca cytochemiczna metodę barwienia (amplifikację sygnału tyramidu) do mierzenia względnej odległości DNA do znakowanych struktur w jądrze, zidentyfikowano około 5\% geno$\mathrm{mu}$, które $\mathrm{z}$ prawdopodobieństwem bliskim 100\% lokalizuje się w odległości <0,32 $\mu \mathrm{m}$ od granicy cętek. Te rejony chromosomowe zostały określone przez autorów jako SPADs 

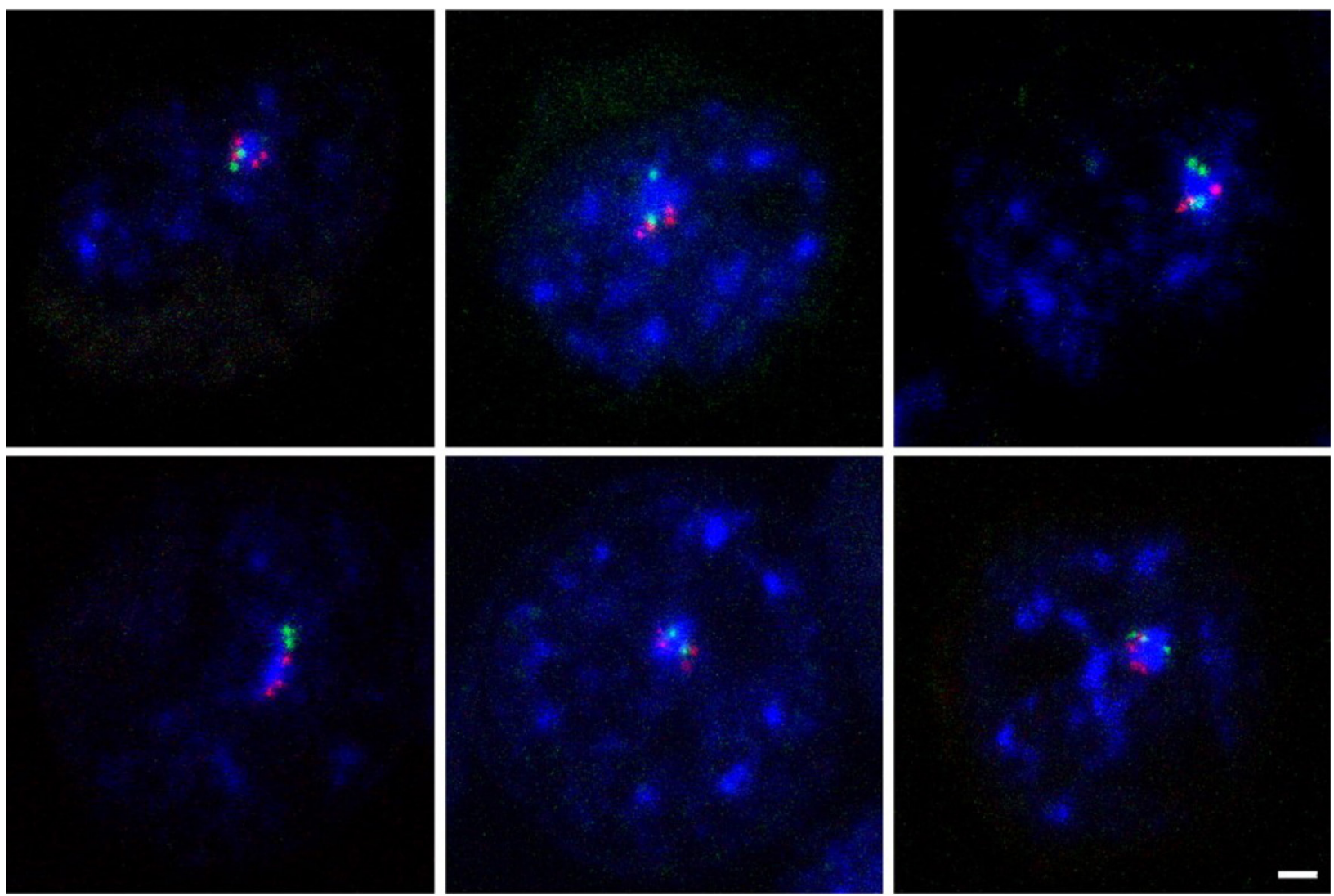

Ryc. 5. Asocjacja aktywnych genów z cętkami. Immuno-FISH dla genów HBA (zielony) i SLC4A1 (czerwony) oraz białka SC35 obecnego w cętkach (niebieski) w erytroblastach podczas erytropoezy.

Znacznik skali $1 \mu \mathrm{m}$. Reprodukowano za zgodą z BRown i współaut. (2008).

(ang. speckle-associated domains) (CHEN i współaut. 2018).

Obecność specyficznego mRNA w cętkach może mieć zwiąek nie $z$ sama transkrypcja, a $z$ dojrzewaniem mRNA i/lub transportem dojrzałych transkryptów do cytoplazmy. W przypadku genu COL1A1 zaobserwowano, że jego transkrypty podlegaja składaniu w pobliżu miejsca transkrypcji, na krawędziach cętek, następnie, bardziej dojrzałe, akumulują się w przyległych cętkach, po czym sa transportowane do cytoplazmy. Z kolei mRNA genu COL1A1, które uległo błędnemu złożeniu (co ma miejsce we wrodzonej łamliwości kości typu 1 i jest zwiazane $z$ mutacją w tym genie) jest w cętkach zatrzymywane (JoHnson 2000). Podobnie, zablokowanie składania mRNA spliceostatyna A, meajamycyna lub pladienolidyna B powoduje odkładanie się transkryptów $\beta$-globiny i $\beta$-aktyny w cętkach komórek mięsaka kościopochodnego linii U2OS. Sa to transkrypty zawierajace introny, a więc takie, które nie uległy składaniu (CARVALHO i współaut. 2017). Slledzac w żywych komórkach U2OS mRNA zawierajace poli(A) ${ }^{+}$zaobserwowano, że przed eksportem do cytoplazmy przechodzi ono przez cętki (MOLENAAR i współaut. 2004).
Kilka innych badań wskazuje, że mRNA wielu genów przechodzi przez cętki (SMITH i współaut. 1999b, MELCAK i współaut. 2000, HATTINGER i współaut. 2002, SHOPLAND i współaut. 2002). Znane sa także prace świadczace o tym, że w cętkach moga mieć miejsce niektóre etapy dojrzewania mRNA. Używajac konstruktów CMV-DNA i śledzac los ich transkryptów w komórkach HeLa pokazano, że pre-mRNA zawierajace funkcjonalne miejsca składania mRNA, odkładane jest w cętkach, podczas gdy transkrypty nie posiadajace funkcjonalnych miejsc składania mRNA, sa równomiernie rozproszone w nukleoplazmie. Metoda FISH $z$ wykorzystaniem sond wykrywajacych składanie RNA wykazano, że proces ten może zachodzić w cętkach (DiAs i współaut. 2010). W cętkach wykryto fosforylowana formę czynnika SF3b155, obecna tylko w katalitycznie aktywnych spliceosomach. Zahamowanie składania mRNA (w wyniku wyciszenia czynnika CDC5L) w komórkach HeLa powoduje akumulację P-SF3b155, tj. spliceosomów, wraz ze składanym mRNA w cętkach, a złagodzenie blokady (w wyniku ekspresji GFP-CDC5L lub mikroiniekcji hPrp19/CDC5L) uwalnia zgromadzone RNA i uruchamia jego eksport (GIRARD 
i współaut. 2012). W komórkach gruczolakoraka nabłonka płuc, mRNA M1 wirusa grypy jest odkładane w cętkach gospodarza, gdzie podlega składaniu. Zaburzanie składania w wyniku deplecji białek cętek NS1-BP lub SON powoduje silna akumulację mRNA w cętkach. Taki sam efekt wywołuje deplecja białek Aly/REF i UAP56, które sa niezbędne do eksportu mRNA M1 i M2 wirusa do cytoplazmy (MoR i współaut. 2016). Cętki zawieraja niewielki, stabilny zasób polimerazy RNA II fosforylowanej na Ser2 C-końcowej domeny, która chociaż jest transkrypcyjnie nieaktywna (co nie wyklucza transkrypcji na obrzeżach cętek), może odgrywać rolę w montażu spliceosomów i składaniu mRNA (XIE i współaut. 2006), wykazano bowiem wcześniej, że ufosforylowana forma polimerazy II promuje taki montaż (ZENG i BERGET 2000) i jest wymagana do zajścia składania (HiRose i współaut. 1999).

Obecność transkryptów niektórych genów w cętkach może być zwiazana $z$ samym tylko eksportem do cytoplazmy. Wykazano, że w komórkach HeLa, mRNA dla JUND, HSPA1A, RHOB i ZXDB, których geny nie zawieraja intronów, przed eksportem do cytoplazmy lokalizuje się w cętkach. Wejście tych transkryptów do cętek jest niezależne od transkrypcji czy obecności ogona poli(A) i jest promowane przez sekwencje ESE i białka SR $z$ nimi się wiążące. Obecność transkryptów w cętkach wzmacnia proces ich transportu do cytoplazmy w wyniku ułatwiania naboru czynników kompleksu TREX (WANG i współaut. 2018).

Wymienione badania były prowadzone w komórkach transformowanych i/lub proliferujacych. Dane te, jak również fakt, że w cętkach obecne sa czynniki biorace udział w eksporcie mRNA do cytoplazmy oraz w procesie NMD wskazuja, że w cętkach może mieć miejsce jeden $z$ punktów „kontroli jakości" mRNA. O ile więc zasadnicza transkrypcja i składanie ma miejsce w nukleoplazmie, to pewne specyficzne geny ulegaja ekspresji w bliskim przestrzennym zwiazku $Z$ cętkami. Cętki moga funkcjonować więc jako subjądrowe domeny, na peryferiach których zachodzi transkrypcja i kotranskrypcyjne składanie, a w ich wnętrzu potranskrypcyjna przejściowa akumulacja bardziej dojrzałego mRNA, prawdopodobnie w celu kontroli i dalszego dojrzewania przed eksportem do cytoplazmy (HALL i współaut. 2006).

Biorac pod uwage powyższe wyniki, HALL i współaut. (2006) zaproponowali rolę cętek, jako ośrodka przestrzennie łacczacego transkrypcję specyficznego mRNA oraz składania i eksportu do cytoplazmy niektórych wysoce aktywnych genów $w$ celu ułatwienia ich efektywnej ekspresji.

\section{CETKI JĄDROWE W KOMÓRKACH NERWOWYCH}

Jak już wspomniałem, obecność cętek w jądrach komórkowych została po raz pierwszy pokazana właśnie w komórkach nerwowych przez Santiago Romóna y Cajala. Cajal również, jako pierwszy scharakteryzował pod względem morfologii i cech cytochemicznych te struktury. Zauważył mianowicie, że w neuronach piramidalnych kory mózgowej i w motoneuronach rdzenia kręgowego występuja okragłe, rzadziej kanciaste twory, które nie wybarwiaja się pod wpływem działania kwaśnej aniliny, barwia się srebrem koloidalnym słabiej niż jąderko i ciałka Cajala, natomiast przy zastosowaniu azotanu srebra przybierają barwę żółtą, pomarańczową lub czerwoną. W neuronach piramidalnych kory mózgowej kota, psa i królika liczbę cętek określił na 6 do 7 , przy średnicy 0,8-1,5 $\mu \mathrm{m}$. Z kolei w ludzkich neuronach kory, ich liczbę oszacował na 6 do 10 (nie podając wielkości). Zauważył równiė̇, że w większych motoneuronach psa i kota, cętki także sa większe, osiagajac 2-3 $\mu \mathrm{m}$ średnicy (nie podajacc liczby) (CAJAL 1910).

Przez długi okres rozwoju wiedzy na temat budowy i znaczenia ciałek jadrowych, pomijano badania organizacji cętek w komórkach nerwowych. Dopiero późniejsze badania Miguela Lafargi i jego grupy zmieniły ten stan rzeczy. Badacze ci (PENA i współaut. 2001) analizowali cętki w neuronach czuciowych zwoju trójdzielnego (łac. ganglion trigeminale) szczurów. W zwoju tym scharakteryzowali trzy typy neuronów różniące się wielkościa i rozmieszczeniem organelli: duże neurony o średnicy ciała 40-75 $\mu \mathrm{m}$ (typ A), średnie o średnicy 20-50 $\mu \mathrm{m}$ (typ B) oraz małe o średnicy poniżej $20 \mu \mathrm{m}$ (typ C). Autorzy wiązali wielkość neuronów $z$ nasileniem aktywności transkrypcyjnej zakładając, że im większy rozmiar komórki, tym większe tempo transkrypcji. Zaobserwowali również korelację pomiędzy wielkościa neuronów a liczba jąderek, ciałek Cajala oraz wielkością i rozproszeniem IGC/cętek. Stwierdzili, że duże neurony (wysoka aktywność transkrypcyjna) posiadaja jedno jąderko, zazwyczaj trzy ciałka Cajala oraz małe IGC/cętki i czynniki składania rozproszone w nukleoplazmie, średnie neurony maja dwa jąderka, jedno ciałko Cajala oraz kilka dużych IGC/cętek, zaś małe neurony - dwa lub trzy jąderka, jedno ciałko Cajala oraz największe IGC/cętki. IGC w neuronach czuciowych zwoju trójdzielnego, podobnie jak w innych komórkach tworza 20-25 nanometrowej średnicy ziarna $\mathrm{w}$ różnym stopniu zagregowania. 
NAVASCUES i współaut. (2004) zauważyli zmianę organizacji IGC/cętek w neuronach zwoju trójdzielnego typu A, w odpowiedzi na uszkodzenie zakończeń aksonalnych wywolany miejscowym podaniem $4 \%$ formaliny: zwiększenie wymiarów cętek $\mathrm{w}$ połączeniu $\mathrm{z}$ intensywniejszym znakowaniem U2 snRNP B", co następowało trzy dni po wywołaniu uszkodzenia. Zmiany ustępowały po około 7. dniach od uszkodzenia. Autorzy wiaża te zmiany $z$ mniejszym nasileniem transkrypcji $\mathrm{w}$ neuronach $\mathrm{z}$ uszkodzonymi zakończeniami, a w konsekwencji zmniejszonym naborem czynników składania do miejsc składania pre-mRNA oraz zwiększona ilościa czynników przechowywanych w cętkach. Znakując miejsca transkrypcyjne poprzez inkorporacje 5-FU do nowopowstającego mRNA wykazano, że w tym modelu centrum cętek nie zawiera miejsc aktywnych transkrypcyjnie. Obecność takich miejsc stwierdzono za to na obrzeżach IGC/cętek (CASAFONT i współaut. 2006). Wydaje się więc, że w neuronach IGC/cętki pod względem morfologii, ultrastruktury i ich zmian w reakcji na stopień nasilenia transkrypcji nie różnia się znaczaco od IGC/cętek w innych komórkach.

W linii komórkowej neuronów ludzkich pochodzenia nowotworowego (neuroblastoma SH-SY5Y) wykazano, że po zadziałaniu na komórki szokiem cieplnym, białka HSPA1A i HSPA6 gromadza sie przy cętkach. Dodatkowo HSPA6 tworzy kuliste skupienia przy cętkach $\mathrm{i}$ pozostaje $\mathrm{z}$ nimi zasocjowane po zakończeniu szoku cieplnego. W poprzednim rozdziale opisałem doniesienia dotyczace aktywnych genów asocjujacych $z$ cetka$\mathrm{mi}$, w tym przedstawiam relację o białkach nie będacych składnikami cętek i ich przestrzennej lokalizacji na obrzeżach tych ciałek. Oba zjawiska sa zapewne $z$ soba powiazane. Białka szoku cieplnego to tzw. białka opiekuńcze. Jedną $z$ ich funkcji jest zabezpieczanie innych białek przed niekorzystnym wpływem czynników stresowych (np. przed denaturacja spowodowana wysoka temperatura). Wiadomo również, że szok cieplny powoduje zahamowanie transkrypcji (VELICHKO i współaut. 2013). SHORBAGI i BROWN (2016) sugeruja, że gromadzenie się białek szoku cieplnego na obrzeżach cętek, a więc w miejscach, gdzie odbywa się transkrypcja niektórych genów, może mieć związek $z$ istnieniem mechanizmu zapewniajacego szybki powrót transkrypcji do stanu sprzed jej hamowania spowodowanym zadziałaniem czynnika stresowego. Brak jest danych literaturowych, czy w innych komórkach, w tym w typowych neuronach, zjawisko czasowego gromadzenia się białek szoku cieplnego przy cętkach ma również miejsce.

\section{CETKI JADROWE W STANACH CHOROBOWYCH}

Istnieje niewielka grupa zaburzeń, w przebiegu których udział cętek jądrowych może mieć znaczenie. Należą do niej niektóre $z$ chorób spowodowanych tzw. powtórzeniami trójnukleotydów (ang. trinucleotide repeat expansion disorders, TREDs), rodzajem mutacji dynamicznych. Powtórzenia trójnukleotydów występuja naturalnie w genomie, zarówno w rejonach kodujących, jak i niekodujacych. Nieprawidłowa i nadmiarowa liczba powtórzeń sekwencji trójek (kodonów) nukleotydów prowadzi do powstania błędnie uformowanego białka zyskujacego toksyczne właściwości, transkryptu (mRNA) o toksycznych właściwościach lub po prostu utraty funkcji przez transkrypt lub białko (KRZYZOSIAK i współaut. 2012).

Jedną $z$ takich chorób jest oczno-gardłowa dystrofia mięśniowa (ang. oculopharyngeal muscular dystrophy, OPMD). Przyczyna OPMD jest mutacja $\mathrm{w}$ genie $P A B P N 1$ polegajaca na pojawieniu się dodatkowych powtórzeń GCG, tj. kodonu alaniny, wydłużajacych trakt polialaninowy z 10 do $12-17$ powtórzeń aminokwasów (RoBINSON i współaut. 2006). W OPMD nieprawidłowe PABPN1 tworzy w miocytach wewnatrzjądrowe agregaty, które lokalizuja się przy granicy cętek. Agregaty te zawieraja także kilka innych białek oraz poly(A) RNA. W takich komórkach ilość białka PABPN1 w cętkach, gdzie ono normalnie występuje, jest znacznie zmniejszona. W ludzkich mioblastach transfekowanych GFP-PABPN1-17ala (konstrukt naśladujacy skutki mutacji w OPMD) agregaty białka PABPN1 także powstaja na obrzeżach cętek, zawieraja przy tym poly(A) RNA, a ich tworzeniu i zwiększaniu się towarzyszy zmniejszanie się ilości PABPN1 i poly(A) RNA w cetkach (BENGOECHEA i wspólaut. 2012). Zdaniem autorów cętki zapewniaja optymalne środowisko do agregacji nieprawidłowego białka: sa miejscem w jadrze, gdzie koncentracja PABPN1 i poly(A) RNA jest najwyższa (prawdopodobnie tworza się kompleksy PABPN1/poly(A) RNA), co zwiększa stopień i specyficzność oddziaływań potrzebnych do oligomeryzacji. W dyskusji pracy grupy RoBINSONA i współaut. (2006) pojawia się także teza, że specyficzna lokalizacja agregatów na peryferiach cętek może być zwiazana $z$ organizacja genomu wokół cętek. Jak się wydaje, cętki sa formowane w bezpośredniej bliskości pewnych genów, w lokalizacji zapewniającej odpowiednia koncentrację czynników składania, dostępnych nowopowstałym transkryptom (HALL i współaut. 2006, RINO i CARMO-FOnSECA 2009). Biorac to pod uwage, prace te sugeruja, że transkrypty mRNA ak- 
tywnych genów położonych w pobliżu cętek inicjuja nukleację agregatów w OPMD. Na potwierdzenie tej tezy przytacza się badania pokazujace, że specyficzne transkrypty RNA moga służyć jako rusztowanie rekrutujace białka oddziałujace $z$ RNA w celu zbudowania takich struktur jadrowych jak cętki, paracętki, histone locus bodies czy jądrowe ciałka stresowe (SHEvTSOV i DUNDR 2011, MAO i współaut. 2011a). Jednym z patologicznych skutków obecności agregatów w miocytach może być zaburzenie alternatywnego składania troponiny $\mathrm{T}$ typu 3 (TNNT3) (a wiec białka specyficznego dla miocytów): agregaty PABPN1 sa zdolne „uwięzič” pre-mRNA TNNT3 tak, że jest ono niedostępne dla SC35, które, jak równocześnie wykazano, jest czynnikiem odpowiedzialnym za alternatywne składanie TNNT3 (KLEIN i współaut. 2016).

Udział cętek jądrowych jest także obserwowany w dystrofii miotonicznej typu I (ang. myotonic dystrophy type 1, łac. dystrophia myotonica 1, DM1), powodowanej mutacja w genie $D M P K$ (ang. dystrophia myotonica protein kinase). Jest to gen kodujacy serynowo-treoninowa kinazę niezbędna w rozwoju miocytów. Wspomniana mutacja skutkuje ekspansja trójnukleotydu CUG w sekwencji 3'UTR. W normalnych mioblastach aktywny gen $D M P K$ lokalizuje się przy granicy cętek, a jego produkt, mRNA DMPK, jest okresowo deponowane w cętkach. Tam najprawdopodobniej białka uczestniczace w składaniu sa wymieniane na białka uczestniczace w transporcie mRNA do porów jadrowych i dalej do cytoplazmy. W chorobie DM1 transport jadrowy mRNA DMKP ulega zaburzeniu: zmutowane transkrypty tego genu choć podlegaja składaniu, nie wchodza do cętek $z$ powodu ich zmienionej struktury oraz zaburzonej interakcji $z$ białkiem MBNL1 (ang. muscleblind-like protein 1), które jest regulatorem alternatywnego składania mRNA (PASCUAL i współaut. 2006). Na granicy cętek tworza się wtedy agregaty zmutowanych transkryptów genu $D M P K$, białka MBNL1 i prawdopodobnie innych białek, a transport transkryptów do cytoplazmy jest zaburzony (HolT i współaut. 2007, SMITH i współaut. 2007).

Nieco odmienny charakter ma lokalizacja agregatów RNA powstajacych w chorobach ekspansji poliglutaminowych [ang. polyglutamine (PolyQ) diseases], gdzie mutacji dynamicznej ulegaja sekwencje zawierajace powtarzany trinukleotyd CAG kodujacy glutaminę. W fibroblastach będacych komórkowymi modelami plassawicy Huntingtona (HD), ataksji móżdżkowo-rdzeniowych typu 1, 3, 7 (DSC1, DSC3, DSC7), zaniku jądra zębatego, jadra czerwiennego, gałki bladej i jadra niskowzgórzowego (ang. dentatorubral-pallidoluysian atrophy, DRPLA, choroba Naito-Oyanagi), zmutowane mRNA (różnych białek, w zależności od choroby) jest deponowane i zatrzymywane nie przy, ale wewnatrz cętek. Zmutowane transkrypty kolokalizuja $z$ wspomnianym w poprzednim akapicie białkiem MBNL1, lecz w znacznie mniejszym stopniu niż w przypadku DM1. Autorzy tłumaczą ten fakt krótszym zmutowanym traktem CAG i mniejszym powinowactwem wiazania MBNL1 do powtórzeń CAG niż do CUG. Mniejszy stopień „zajęcia” powtórzeń CAG przez MBNL1, tłumaczy $z$ kolei dlaczego wchodza one do cętek i tam dopiero sa blokowane, a w przypadku mięśniowego mRNA, DMPK1 jest zatrzymywane już na obrzeżach cętek (URBANEK i współaut. 2016).

W zespole drżenia i ataksji zwiazanych $z$ łamliwym chromosomem $X$ (ang. fragile X-associated tremor/ataxia syndrome, FXTAS), obserwuje się ekspansję powtórzeń CGG w 5'-UTR genu FMR1. Gen ten koduje białko FMRP (ang. fragile $X$ mental retardation protein), wiążące RNA i zaangażowane w różne etapy jego metabolizmu, szczególnie w neuronach (D’ANNESSA i współaut. 2019). Zmutowane sekwencje CGG również prowadza do agregacji nieprawidłowych transkryptów w cętkach (SELLIER i współaut. 2010).

Odkładanie się nieprawidłowego mRNA w cętkach występuję nie tylko w chorobach TRED: we wrodzonej łamliwości kości typu 1 (ang. osteogenesis imperfecta type 1, OI 1), defekt w przebiegu składania genu kolagenu 1a1 (COL1A1) prowadzi do akumulacji zmutowanego RNA tego genu w cętkach fibroblastów (JoHnson 2000).

Jak można zauważyć, we wszystkich wymienianych jednostkach chorobowych powtarza się ten sam schemat, w którym nieprawidłowe mRNA tworzy złogi/wtręty/agregaty w cętkach lub na ich obrzeżach. Ta obserwacja wspiera hipoteze, że w przypadku ekspresji niektórych genów, cętki moga być specyficznym punktem kontrolnym poprawności złożenia i nieobecności mutacji pre-mRNA (MOLENAAR i współaut. 2004, SMITH i współaut. 2007).

\section{PODZIEKOWANIA}

Serdecznie dziękuje prof. dr hab. Grzegorzowi Wilczyńskiemu (IBD PAN) za cenne wskazówki oraz prof. dr hab. Andrzejowi Wróblowi za krytyczne uwagi do artykułu.

$$
\text { Streszczenie }
$$

Jądro komórkowe oprócz heterochromatyny czyli kompleksu DNA i białek histonowych, zawiera struktury zwane ciałkami jądrowymi (ang. nuclear bodies). Sa to niewielkie, zazwyczaj koliste twory „zawieszone” w nukleoplazmie, składające się $z$ białek lub białek i niekodującego RNA. Znanych jest kilkanaście rodzajów takich 
struktur. Artykuł przedstawia obecny stan wiedzy na temat ciałek nazywanych w angielskiej literaturze nuclear speckles, czyli cętki jądrowe lub interchromatin granule clusters czyli skupiska ziaren interchromatynowych. Zaobserwowane po raz pierwszy przez Romana y Cajala w neuronach, obecne jednak we wszystkich typach komórek, struktury te uważane sa za magazyny i miejsce modyfikacji czynników składania (splicingu) mRNA. Najnowsze badania, prezentowane $\mathrm{w}$ artykule pozwalaja sązić, że ich udział w metabolizmie RNA jest bardziej złożony. Świadcza o tym również doniesienia o roli cẹtek jadrowych w dziedzicznych chorobach powodowanych powtórzeniami trójnukleotydów, w tym tych o skutkach neurologicznych.

\section{LITERATURA}

BECK J. S., 1961. Variations in the morphological patterns of "autoimmune" nuclear fluorescence. Lancet 277, 1203-1205.

Belin B. J., Cimini B. A., BlackBurn E. H., MulLINS R. D., 2013. Visualization of actin filaments and monomers in somatic cell nuclei. Mol. Biol. Cell 24, 982-994.

BENGOECHEA R., TAPIA O., CASAFONT I., BERCIANO J., LAFARGA M., BERCIANO M. T., 2012. Nuclear speckles are involved in nuclear aggregation of PABPN1 and in the pathophysiology of oculopharyngeal muscular dystrophy. Neurobiol. Dis. 46, 118-129.

BERNARD D., PRASANTH K. V., TRIPATHI V., COLASSE S., NaKamura T., Xuan Z., Zhang M. Q., SEDEL F., JOURDREN L., COULPIER F., TRILLER A., Spector D. L., Bessis A., 2010. A long nuclear-retained non-coding RNA regulates synaptogenesis by modulating gene expression. EMBO J. 29, 3082-3093.

BERNHARD W., 1969. A new staining procedure for electron microscopical cytology. J. Ultrastruct. Res. 27, 250-265.

BIAMONTI G., VOURC'H C., 2010. Nuclear Stress Bodies. Cold Spring Harbor Perspectives in Biology 2. doi: 10.1101/cshperspect.a000695

BORONENKOV I. V., LOIJENS J. C., UMEDA M., ANDERSON R. A., 1998. Phosphoinositide signaling pathways in nuclei are associated with nuclear speckles containing pre-mRNA processing factors. Mol. Biol. Cell 9, 3547-3560.

BRASCH K., OCHS R. L., 1992. Nuclear bodies (NBs): a newly "rediscovered" organelle. Exp. Cell Res. 202, 211-223.

Brede G., SOlHeim J., PRYDZ H., 2002. PSKH1, a novel splice factor compartment-associated serine kinase. Nucleic Acids Res. 30, 53015309.

BREGMAN D. B., DU L., VAN DER ZEE S., WARREN S. L., 1995. Transcription-dependent redistribution of the large subunit of RNA polymerase II to discrete nuclear domains. J. Cell Biol. 129, 287-298.

BRIDGE E., 1995. Dynamic organization of splicing factors in adenovirus-infected cells. J. Virol. 69, 281-290.

Brown J. M., Leach J., ReitTie J. E., AtZBERger A., LEe-PRUdHOE J., WOOD W. G., HigGS D. R., IBORRA F. J., BUCKLE V. J., 2006. Coregulated human globin genes are frequently in spatial proximity when active. J. Cell Biol. $172,177-187$.

Brown J. M., Green J., Neves R. P. D., Wallace H. A. C., Smith A. J. H., Hughes J., GraY N., TAYlOR S., WOOD W. G., HigGS D. R., IBORRA F. J., BUCKLE V. J., 2008. Association between active genes occurs at nuclear spec- kles and is modulated by chromatin environment. J. Cell Biol. 182, 1083-1097.

Bubulya P. A., Prasanth K. V., DeERINCK T. J., Gerlich D., Beaudouin J., Ellisman M. H., EllenBerG J., SPECTOR D. L., 2004. Hypophosphorylated SR splicing factors transiently localize around active nucleolar organizing regions in telophase daughter nuclei. J. Cell Biol. 167, 51-63.

Caceres J. F., Misteli T., Screaton G. R., SpecTOR D. L., KRAINER A. R., 1997. Role of the modular domains of $S R$ proteins in subnuclear localization and alternative splicing specificity. J. Cell Biol. 138, 225-238.

CAJAL S. R., 1910. El núcleo de las células piramidales del cerebro humano y de algunos mamíferos. Trab. Lab. Invest. Biol. 8, 35.

Carter K. C., TANEJA K. L., Lawrence J. B., 1991. Discrete nuclear domains of poly $(A)$ RNA and their relationship to the functional organization of the nucleus. J. Cell Biol. 115, 1191-1202.

Carvalho T., Martins S., Rino J., Marinho S., CARMO-FONSECA M., 2017. Pharmacological inhibition of the spliceosome subunit $S F 3 b$ triggers exon junction complex-independent nonsense-mediated decay. J. Cell Sci. 130, 15191531.

Casafont I., Navascues J., Pena E., Lafarga M., BERCIANO M. T., 2006. Nuclear organization and dynamics of transcription sites in rat sensory ganglia neurons detected by incorporation of 5'-fluorouridine into nascent RNA. Neuroscience $140,453-462$.

Chen W. Y., Lee W. C., Hsu N. C., Huang F., CHUNG B. C., 2004. SUMO modification of repression domains modulates function of nuclear receptor $5 A 1$ (steroidogenic factor-1). J. Biol. Chem. 279, 38730-38735.

Chen Y., Zhang Y., WANG Y., Zhang L., BRINKMAN E. K., Adam S. A., Goldman R., van SteEnSEL B., MA J., BELMONT A. S., 2018. Mapping 3D genome organization relative to nuclear com partments using TSA-Seg as a cytological ruler. J. Cell Biol. 217, 4025-4048.

CMARKO D., 1999. Ultrastructural analysis of transcription and splicing in the cell nucleus after bromo-UTP microinjection. Mol. Biol. Cell 10, 211-223.

Colwill K., PaWson T., Andrews B., Prasad J., Manley J. L., Bell J. C., DunCAN P. I., 1996. The Clk/Sty protein kinase phosphorylates SR splicing factors and regulates their intranuclear distribution. EMBO J. 15, 265-275.

Courchaine E. M., LU A., NEUGEBAUER K. M., 2016. Droplet organelles? EMBO J. 35, 16031612.

D'ANNESSA I., CiCCONARDI F., Di MARINO D., 2019. Handling FMRP and its molecular partners: Structural insights into Fragile $X$ Syndrome. Prog. Biophys. Mol. Biol. 141, 3-14.

Dellaire G., MAKarov E. M., COWGer J. J., LONGMAN D., SUTHERLAND H. G., LUHRMANN R., TORCHIA J., BICKMORE W. A., 2002. Mammalian PRP4 kinase copurifies and interacts with components of both the U5 snRNP and the $\mathrm{N}$-CoR deacetylase complexes. Mol. Cell. Biol. 22, 5141-5156.

Dias A. P., DUfU K., LEI H., REed R., 2010. A role for TREX components in the release of spliced mRNA from nuclear speckle domains. Nat. Commun. 1, 97. doi: 10.1038/ ncomms 1103

FAKAN S., LESER G., MARTIN T. E., 1984. Ultrastructural distribution of nuclear ribonucleopro- 
teins as visualized by immunocytochemistry on thin sections. J. Cell Biol. 98, 358-363.

FANG Y., HEARN S., SpeCtOR D. L., 2004. Tissue-specific expression and dynamic organization of SR splicing factors in Arabidopsis. Mol. Biol. Cell 15, 2664-2673.

Fei J., JaDaliha M., Harmon T. S., Li I. T. S., Hua B., Hao Q., Holehouse A. S., Reyer M., Sun Q., Freier S. M., PAPPU R. V., PRASANTH K. V., HA T., 2017. Quantitative analysis of multilayer organization of proteins and RNA in nuclear speckles at super resolution. J. Cell Sci. 130, 4180-4192.

FERREIRA J. A., CARMO-FonsecA M., LAMOND A. I., 1994. Differential interaction of splicing snRNPs with coiled bodies and interchromatin granules during mitosis and assembly of daughter cell nuclei. J. Cell Biol. 126, 11-23.

Fox A. H., LAMOND A. I., 2010. Paraspeckles. Cold Spring Harb. Perspect. Biol. 2, doi: $10.1101 /$ cshperspect.a000687

GALGANSKI L., URBANEK M. O., KRZYZOSIAK W. J., 2017. Nuclear speckles: molecular organization, biological function and role in disease. Nucleic Acids Res. 45, 10350-10368.

Gall J. G., Bellini M., Wu Z., MurPhy C., 1999. Assembly of the nuclear transcription and processing machinery: Cajal bodies (coiled bodies) and transcriptosomes. Mol. Biol. Cell 10, 4385-4402.

Geuens T., Bouhy D., Timmerman V., 2016. The hnRNP family: insights into their role in health and disease. Hum. Genet. 135, 851-867.

Girard C., Will C. L., Peng J., Makarov E. M., Kastner B., LEMm I., URLAUB H., HaRTMUTH K., LUHRMANN R., 2012. Post-transcriptional spliceosomes are retained in nuclear speckles until splicing completion. Nat. Commun. 3, 994. doi: 10.1038/ncomms 1998

GRANBOULAN N., BERNHARD W., 1961. Ultrastructural cytochemistry. Exploration of nuclear structures by enzymatic digestion. C. R. Seances Soc. Biol. Fil. 155, 1767-1779.

Gui J. F., Lane W. S., Fu X. D., 1994. A serine kinase regulates intracellular localization of splicing factors in the cell cycle. Nature 369, 678-682.

Hall L. L., Smith K. P., Byron M., Lawrence J. B., 2006. Molecular anatomy of a speckle. Anat. Rec. A Discov. Mol. Cell. Evol. Biol. $288,664-675$

HANDWERGER K. E., GALl J. G., 2006. Subnuclear organelles: new insights into form and function. Trends. Cell Biol. 16, 19-26.

Hattinger C. M., Jochemsen A. G., TANKe H. J., DIRKS R. W., 2002. Induction of p21 mRNA synthesis after short-wavelength UV light visualized in individual cells by RNA FISH. J. Histochem. Cytochem. 50, 81-89.

HETT A., WEST S., 2014. Inhibition of U4 snRNA in Human Cells Causes the Stable Retention of Polyadenylated Pre-mRNA in the Nucleus. PLoS One 9. doi: 10.1371/journal. pone.0096174

Hirose Y., TACKe R., Manley J. L., 1999. Phosphorylated RNA polymerase II stimulates pre-mRNA splicing. Genes. Dev. 13, 1234-1239.

Holt I., MitTal S., Furling D., Butler-Browne G. S., BROOK J. D., MORRIS G. E., 2007. Defective mRNA in myotonic dystrophy accumulates at the periphery of nuclear splicing speckles. Genes Cells 12, 1035-1048.

HuANG S., SPECTOR D. L., 1991. Nascent pre- mRNA transcripts are associated with nuclear regions enriched in splicing factors. Genes Dev. 5, 2288-2302.
Huang S., Deerinck M. H., Ellisman M. H., SpecTOR D. L., 1994. In vivo analysis of the stability and transport of nuclear poly $(A)+R N A$. J. Cell Biol. 126, 877-899.

Hutchinson J. N., Ensminger A. W., Clemson C. M., LYNCH C. R., LAWRENCE J. B., CHESS A., 2007. A screen for nuclear transcripts identifies two linked noncoding RNAs associated with SC35 splicing domains. BMC Genomics 8, 39.

Hyman A. A., Weber C. A., Julicher F., 2014. Liquid-liquid phase separation in biology. Annu. Rev. Cell Dev. Biol. 30, 39-58.

IBORRA F. J., JACKSON D. A., COOK P. R., 1998. The path of transcripts from extra-nucleolar synthetic sites to nuclear pores: transcripts in transit are concentrated in discrete structures containing SR proteins. J. Cell Sci. 111, 2269-2282

JAGATHEESAN G., 1999. Colocalization of intranuclear lamin foci with RNA splicing factors. J. Cell Sci. 112, 4651-4661.

Ji P., DiederichS S., WANG W., BoIng S., MeTZGER R., SchneIder P. M., TIDOW N., BRANDT B., Buerger H., BulK E., Thomas M., BerDEL W. E., Serve H., Muller-Tidow C., 2003. MALAT-1, a novel noncoding RNA, and thymosin beta4 predict metastasis and survival in early-stage non-small cell lung cancer. Oncogene 22, 8031-8041.

JOHNSON C., 2000. Tracking COL1A1 RNA in osteogenesis imperfecta. Splice-defective transcripts initiate transport from the gene but are retained within the SC35 domain. J. Cell Biol. $150,417-432$

JOLlY C., VOURC'H C., ROBERT-NiCOUd M., MORIMOTO R. I., 1999. Intron-independent association of splicing factors with active genes. J. Cell Biol. 145, 1133-1143.

Kaida D., Motoyoshi H., TASHiro E., NoJima T., HAGIWARA M., ISHIGAMI K., WATANABE H., KITAHARA T., YOSHIDA T., NAKAJIMA H., TANI T., HORINOUCHI S., YOSHIDA M., 2007. Spliceostatin A targets $S F 3 b$ and inhibits both splicing and nuclear retention of pre-mRNA. Nat. Chem. Biol. 3, 576-583.

Kim J., HaN K. Y., KHANNA N., HA T., BELMONT A. S., 2019. Nuclear speckle fusion via long-range directional motion regulates speckle morphology after transcriptional inhibition. J. Cell Sci. 132 .

KIss T., 2004. Biogenesis of small nuclear RNPs. J. Cell Sci. 117, 5949-5951.

Klein P., OlOKo M., Roth F., Montel V., MalerBA A., JARMin S., GidARO T., POPPlewell L., Perie S., Lacau St Guily J., DE la Grange P., ANTONIOU M. N., Dickson G., BUTLER-BROWNE G., BASTIDE B., MOUlY V., TROllet C., 2016. Nuclear poly(A)-binding protein aggregates misplace a pre-mRNA outside of SC35 speckle causing its abnormal splicing. Nucleic Acids. Res. 44, 10929-10945.

Ko T. K., Kelly E., PINES J., 2001. CrkRS: a novel conserved Cdc2-related protein kinase that colocalises with SC35 speckles. J. Cell Sci. 114, 2591-2603.

Krause S., Fakan S., Weis K., Wahle E., 1994. Immunodetection of poly $(A)$ binding protein II in the cell nucleus. Exp. Cell Res. 214, 75-82.

KRZYZOSIAK W. J., SOBCZAK K., WOJCIECHOWSKA M., FISZER A., MYKOWSKA A., KOZLOWSKI P., 2012. Triplet repeat RNA structure and its role as pathogenic agent and therapeutic target. Nucleic Acids. Res. 40, 11-26.

KumAR Y., BHATIA A., MinZ R. W., 2009. Antinuclear antibodies and their detection methods 
in diagnosis of connective tissue diseases: a journey revisited. Diagn. Pathol. 4, 1. doi: 10.1186/1746-1596-4-1

LAFARGA M., CASAFONT I., BEngOECHEA R., TAPIA O., BERCIANO M. T., 2009. Cajal's contribution to the knowledge of the neuronal cell nucleus. Chromosoma 118, 437-443.

LALlEMAND-BREITENBACH V., DE THE H., 2010. PML nuclear bodies. Cold Spring Harb. Perspect. Biol. 2. doi: 10.1101/cshperspect.a000661

Le Hir H., GatField D., BRAUN I. C., Forler D., IZAURRALDE E., 2001. The protein Mago provides a link between splicing and mRNA localization. EMBO Rep. 2, 1119-1124.

LEEUWENHOEK A. V., 1682. An account of several very curious discoveries about the internal texture of the flesh of muscles, of strange motions in the finns, and the manner of the production of the shells of oysters, \&c. made by $M r$. Anthony Leuwenhoek fellow of the Royal Society; sent in a letter to $R$. $H$. from Delft, and by him exhibited to the said Society. Philosop. Collect. Royal Soc. London 5, 152-160.

LERNER M. R., STEITZ J. A., 1979. Antibodies to small nuclear RNAs complexed with proteins are produced by patients with systemic lupus erythematosus. Proc. Natl. Acad. Sci. USA 76, 5495-5499.

LESER G. P., FAKAN S., MaRTin T. E., 1989. Ultrastructural distribution of ribonucleoprotein complexes during mitosis. snRNP antigens are contained in mitotic granule clusters. Eur. J. Cell Biol. 50, 376-389.

Li L., Roy K., Katyal S., Sun X., Bléoo S., GodBOUT R., 2006. Dynamic Nature of Cleavage Bodies and Their Spatial Relationship to DDX 1 Bodies, Cajal Bodies, and Gems. Mol. Biol. Cell 17, 1126-1140.

LOCKE M., HUIE P., 1977. Bismuth staining for light and electron microscopy. Tissue Cell 9, 347-371.

LONG J. C., CACERES J. F., 2009. The SR protein family of splicing factors: master regulators of gene expression. Biochem. J. 417, 15-27.

Machyna M., HeYn P., NEUGEBAUER K. M., 2013. Cajal bodies: where form meets function. Wiley Interdiscip. Rev. RNA 4, 17-34.

MaO Y. S., Sunwoo H., Zhang B., Spector D. L., 2011a. Direct visualization of the co-transcriptional assembly of a nuclear body by noncoding RNAs. Nat. Cell Biol. 13, 95-101.

MaO Y. S., Zhang B., Spector D. L., 2011b. Biogenesis and function of nuclear bodies. Trends Genet. 27, 295-306

MARNEF A., WEIL D., STANDART N., 2012. RNA-related nuclear functions of human Pat1b, the P-body mRNA decay factor. Mol Biol. Cell. 23, 213-224.

MelcaK I., Cermanova S., JiRsova K., Koberna K., MALINSKY J., RASKA I., 2000. Nuclear pre-mRNA compartmentalization: trafficking of released transcripts to splicing factor reservoirs. Mol. Biol. Cell 11, 497-510.

Mellman D. L., Gonzales M. L., SOng C., BarLOW C. A., Wang P., Kendziorski C., ANDERSON R. A., 2008. A PtdIns4,5P2-regulated nuclear poly(A) polymerase controls expression of select mRNAs. Nature 451, 1013-1017.

Mermoud J. E., COHEN P. T. W., LAMOND A. I., 1994. Regulation of mammalian spliceosome assembly by a protein phosphorylation mechanism. ЕMBO J. 13, 5679-5688.

MiSTELI T., 1998. Serine phosphorylation of SR proteins is required for their recruitment to sites of transcription in vivo. J. Cell Biol. 143, 297-307.
Misteli T., CACERES J. F., SpeCtor D. L., 1997. The dynamics of a pre-mRNA splicing factor in living cells. Nature 387, 523-527.

MiYAGAWA R., TANO K., MiZUNO R., NAKAMURA Y., IJIRI K., RAKWAL R., SHIBATO J., MASUO Y., MAYEdA A., HiRose T., AKIMITSU N., 2012. Identification of cis- and trans-acting factors involved in the localization of MALAT-1 noncoding RNA to nuclear speckles. RNA 18, 738751 .

Moen JR P. T., Johnson C. V., BYron M., SHOPLAND L. S., DE LA SERNA I. L., IMBALZANO A. N., LAWRENCE J. B., 2004. Repositioning of Muscle-specific Genes Relative to the Periphery of SC-35 Domains during Skeletal Myogenesis. Mol. Biol. Cell 15, 197-206.

MolenaAr C., ABDUlle A., GenA A., TANKe H. J., DIRKS R. W., 2004. Poly(A)+ RNAs roam the cell nucleus and pass through speckle domains in transcriptionally active and inactive cells. J. Cell Biol. 165, 191-202.

MONNERON A., BERNHARD W., 1969. Fine structural organization of the interphase nucleus in some mammalian cells. J. Ultrastruct. Res. 27, 266-288.

Mor A., WhiTe A., Zhang K., Thompson M., EspaRZA M., MUNOZ-MORENO R., KOIDE K., LYNCH K. W., GARCIA-SASTRE A., FONTOURA B. M., 2016. Influenza virus mRNA trafficking through host nuclear speckles. Nat. Microbiol. 1, 16069.

MorRIS G. E., 2008. The Cajal body. Biochim. Biophys. Acta. 1783, 2108-2115.

MORTILLARO M. J., 1996. A hyperphosphorylated form of the large subunit of RNA polymerase II is associated with splicing complexes and the nuclear matrix. Proc. Natl Acad. Sci. USA 93, 8253-8257.

NAKAGAWA S., HIROSE T., 2012. Paraspeckle nuclear bodies - useful uselessness? Cell. Mol. Life Sci. 69, 3027-3036.

NAKAGAWA S., IP J. Y., SHIOI G., TRIPATHI V., ZONG X., Hirose T., Prasanth K. V., 2012. Malat1 is not an essential component of nuclear speckles in mice. RNA 18, 1487-1499.

NAKAYASU H., UEDA K., 1984. Small nuclear RNA-protein complex anchors on the actin filaments in bovine lymphocyte nuclear matrix. Cell Struct. Funct. 9, 317-325.

NAVASCUES J., CASAFONT I., Villagra N. T., LAFARGA M., BERCIANO M. T., 2004. Reorganization of nuclear compartments of type A neurons of trigeminal ganglia in response to inflammatory injury of peripheral nerve endings. J. Neurocytol. 33, 393-405.

Niedojadlo J., MikUlski Z., Delenko K., SZMidT-JAWORSKA A., SMOLINSKI D. J., EPSTEIN A. L., 2012. The perichromatin region of the plant cell nucleus is the area with the strongest co-localisation of SnRNA and SR proteins. Planta 236, 715-726.

Nielsen J. A., Hudson L. D., ARmstrong R. C., 2002. Nuclear organization in differentiating oligodendrocytes. J. Cell Sci. 115, 4071-4079.

Nyman U., Hallman H., Hadlaczky G., PetTersSON I., SHARP G., RINGERTZ N. R., 1986. Intra nuclear localization of snRNP antigens. J. Cell Biol. 102, 137-144.

O'KeEFe R. T., MaYeda A., SAdowski C. L., KraINER A. R., SPECTOR D. L., 1994. Disruption of pre-mRNA splicing in vivo results in reorganization of splicing factors. J. Cell Biol. 124, 149-160

OKADA M., JANG S. W., YE K., 2008. Akt phosphorylation and nuclear phosphoinositide association mediate $m R N A$ export and cell pro- 
liferation activities by $A L Y$. Proc. Natl. Acad. Sci. USA 105, 8649-8654.

PASCUAl M., VicENTE M., MONFERRER L., ARTERO R., 2006. The Muscleblind family of proteins: an emerging class of regulators of developmentally programmed alternative splicing. Differentiation 74, 65-80.

Pederson T., 2011. The nucleolus. Cold Spring Harb. Perspect. Biol. 3. doi: 10.1101/cshperspect.a000638

Pena E., Berciano M. T., Fernandez R., OJeda J. L., LAFARGA M., 2001. Neuronal body size correlates with the number of nucleoli and Cajal bodies, and with the organization of the splicing machinery in rat trigeminal ganglion neurons. J. Comp. Neurol. 430, 250-263.

PHAIR R. D., Misteli T., 2000. High mobility of proteins in the mammalian cell nucleus. Nature 404, 604-609.

Ping X. L., Sun B. F., Wang L., XiaO W., Yang X., WANG W. J., ADHIKARI S., SHI Y., LV Y., Chen Y. S., ZHAO X., LI A., YANG Y., DAHAL U., LOU X. M., LIU X., Huang J., Yuan W. P., ZHu X. F., Cheng T., ZhaO Y. L., WANG X., RENDTLEW DANIELSEN J. M., LIU F., YANG Y. G., 2014. Mammalian WTAP is a regulatory subunit of the RNA N6-methyladenosine methyltransferase. Cell Res. 24, 177-189.

PIRROTTA V., LI H. B., 2012. A view of nuclear Polycomb bodies. Curr. Opin. Genet. Dev. 22, 101-109.

Potashkin J. A., DERBY R. J., SPECTOR D. L., 1990. Differential distribution of factors involved in pre-mRNA processing in the yeast cell nucleus. Mol. Cell. Biochem. 10, 3524-3534.

PRASANTH K. V., SACCO-BubUlya P., PRASANTH S. G., SPECTOR D. L., 2003. Sequential entry of components of gene expression machinery into daughter nuclei. Mol. Biol. Cell 14, 10431057.

Puvion E., Viron A., Assens C., Leduc E. H., JeANTEUR P., 1984. Immunocytochemical identification of nuclear structures containing snRNPs in isolated rat liver cells. J. Ultrastruct. Res. 87, 180-189.

Puvion E., PUVION-Dutilleul F., 1996. Ultrastructure of the nucleus in relation to transcription and splicing: roles of perichromatin fibrils and interchromatin granules. Exp. Cell Res. 229, 217-225.

Quinodoz S. A., Ollikainen N., TABAK B., Palla A., SCHMidT J. M., DETMAR E., LaI M. M., SHISHKIN A. A., BHAT P., TAKEI Y., TRINH V., AZnauryan E., Russell P., Cheng C., JovanoVIC M., CHOW A., CAI L., MCDONEL P., GARBER M., GUTTMAN M., 2018. Higher-Order Inter-chromosomal Hubs Shape 3D Genome Organization in the Nucleus. Cell 174, 744-757 e724.

REUTER R., APPEL B., RINKE J., LUHRMANN R., 1985. Localization and structure of snRNPs during mitosis. Immunofluorescent and biochemical studies. Exp. Cell Res. 159, 63-79.

Rieder D., Ploner C., Krogsdam A. M., Stocker G., Fischer M., SCHEIDEleR M., DANI C., AMRI E. Z., Muller W. G., MCNally J. G., TraJANOSKI Z., 2014. Co-expressed genes prepositioned in spatial neighborhoods stochastically associate with SC35 speckles and RNA polymerase II factories. Cell. Mol. Life Sci. 71, 1741-1759.

Rino J., CARMO-FonseCA M., 2009. The spliceosome: a self-organized macromolecular machine in the nucleus? Trends Cell Biol. 19, 375-384.

RoBinson D. O., Wills A. J., HAMMANS S. R., READ S. P., Sillibourne J., 2006. Oculopha- ryngeal muscular dystrophy: a point mutation which mimics the effect of the PABPN1 gene triplet repeat expansion mutation. J. Med. Genet. 43, e23.

Sacco-Bubulya P., Spector D. L., 2002. Disassembly of interchromatin granule clusters alters the coordination of transcription and pre- $m R N A$ splicing. J. Cell Biol. 156, 425-436.

Saitoh N., Spahr C. S., PatTerson S. D., BubuLYA P., NeuWALD A. F., SPECTOR D. L., 2004. Proteomic analysis of interchromatin granule clusters. Mol. Biol. Cell 15, 3876-3890.

SAWYER I. A., STURGILl D., DUNDR M., 2019. Membraneless nuclear organelles and the search for phases within phases. Wiley Interdiscip. Rev. RNA 10, e1514.

SCHMIDT U., RICHTER K., BERGER A. B., LICHTER P., 2006. In vivo BiFC analysis of Y14 and NXF1 mRNA export complexes: preferential localization within and around SC35 domains. J. Cell Biol. 172, 373-381.

SCHUL W., VAN DRIEL R., DE JONG L., 1998. A subset of poly(A) polymerase is concentrated at sites of RNA synthesis and is associated with domains enriched in splicing factors and poly(A) RNA. Exp. Cell Res. 238, 1-12.

SEGALAT L., LEPESANT J. A., 1992. Spatial distribution of the Sm antigen in Drosophila early embryos. Biol. Cell 75, 181-185.

Sellier C., Rau F., LiU Y., Tassone F., Hukema R. K., GATTONI R., SCHNEIDER A., RICHARD S., Willemsen R., ElliotT D. J., HAGerman P. J., CHARLET-BERGUERAND N., 2010. Sam68 sequestration and partial loss of function are associated with splicing alterations in FXTAS patients. EMBO J. 29, 1248-1261.

SHEPARD P. J., HERTEL K. J., 2009. The SR protein family. Genome Biol. 10, 242.

SHEVTSOV S. P., DUNDR M., 2011. Nucleation of nuclear bodies by RNA. Nat. Cell Biol. 13, 167-173.

SHopland L. S., Johnson C. V., LAWREnCE J. B., 2002. Evidence that all SC-35 domains contain MRNAs and that transcripts can be structurally constrained within these domains. J. Struct. Biol. 140, 131-139.

SHOPLAND L. S., JOHNSON C. V., BYRON M., MCNEIL J., LAWRENCE J. B., 2003. Clustering of multiple specific genes and gene-rich $R$-bands around SC-35 domains: evidence for local euchromatic neighborhoods. J. Cell Biol. 162, 981-990.

SHORBAGI S., BROWN I. R., 2016. Dynamics of the association of heat shock protein HSPA6 (Hsp7OB') and HSPA1A (Hsp70-1) with stress-sensitive cytoplasmic and nuclear structures in differentiated human neuronal cells. Cell Stress Chaperones 21, 993-1003.

SKARE P., KREIVI J. P., BERGSTROM A., KARLSSON R., 2003. Profilin I colocalizes with speckles and Cajal bodies: a possible role in pre-mRNA splicing. Exp. Cell Res. 286, 12-21.

SMith K. P., BYron M., Johnson C., XING Y., LAWRENCE J. B., 2007. Defining early steps in mRNA transport: mutant mRNA in myotonic dystrophy type I is blocked at entry into $S C$ 35 domains. J. Cell Biol. 178, 951-964.

Smith K. P., Moen P. T., Wydner K. L., ColeMAN J. R., LAWRENCE J. B., 1999a. Processing of endogenous pre-mRNAs in association with SC-35 domains is gene specific. J. Cell Biol. 144, 617-629.

Smith K. P., Moen P. T., Wydner K. L., ColeMAN J. R., LAWRENCE J. B., 1999b. Processing of endogenous pre-mRNAs in association with 
SC-35 domains is gene specific. J. Cell Biol.9 9 144, 617-629.

Soboleva T. A., PARKer B. J., NeKrasov M., HART-Smith G., TAY Y. J., Tng W. Q., Wilkins M., RYAN D., TREMETHick D. J., 2017. A new link between transcriptional initiation and pre- $m R N A$ splicing: The RNA binding histone variant H2A.B. PLoS Genet 13, doi: 10.1371/ journal.pgen. 1006633.

SPECTOR D. L., LAMOND A. I., 2011. Nuclear speckles. Cold Spring Harb. Perspect. Biol. 3. doi: 10.1101/cshperspect.a000646.

SPECTOR D. L., SCHRIER W. H., Busch H., 1983. Immunoelectron microscopic localization of snRNPs. Biol. Cell 49, 1-10.

Spector D. L., Fu X. D., Maniatis T., 1991. Associations between distinct pre-mRNA splicing components and the cell nucleus. EMBO J. 10, 3467-3481.

SWIFT H., 1959. Studies on nuclear fine structure. Brookhaven Symp. Biol. 12, 134-152.

SZCZERBAL I., BRIDGER J. M., 2010. Association of adipogenic genes with SC-35 domains during porcine adipogenesis. Chromosome Res. 18, 887-895.

TAN E. M., 1967. Relationship of nuclear staining patterns with precipitating antibodies in systemic lupus erythematosus. J. Lab. Clin. Med. $70,800-812$.

TAN E. M., Kunkel H. G., 1966. Characteristics of a soluble nuclear antigen precipitating with sera of patients with systemic lupus erythematosus. J. Immunol. 96, 464-471.

THIRY M., 1995. The interchromatin granules. Histol. Histopathol. 10, 1035-1045.

TRINKLE-MULCAHY L., 1999. Nuclear organisation of NIPP1, a regulatory subunit of protein phosphatase 1 that associates with pre-mRNA splicing factors. J. Cell Sci. 112, 157-168.

Tripathi V., Ellis J. D., Shen Z., SONG D. Y. PAN Q., WATT A. T., FREIER S. M., BENNETT C. F., Sharma A., Bubulya P. A., Blencowe B. J., PRAsanth S. G., PRASANTH K. V., 2010. The nuclear-retained noncoding RNA MALAT1 regulates alternative splicing by modulating $S R$ splicing factor phosphorylation. Mol. Cell 39, 925-938.

TwyFfEls L., Gueydan C., KRUYS V., 2011. Shuttling SR proteins: more than splicing factors. FEBS J. 278, 3246-3255.

URBANEK M. O., JAZUREK M., Switonski P. M., FIGURA G., KRZYZOSIAK W. J., 2016. Nuclear speckles are detention centers for transcripts containing expanded CAG repeats. Biochim. Biophys. Acta 1862, 1513-1520.
VAN DER LEE R., BULJAN M., LANG B., WEATHERITT R. J., DAUGhDrill G. W., DUNKer A. K., FUXREITER M., GOUGH J., GSPONER J., JONES D. T., KIM P. M., KRIWACKI R. W., OldFIELD C. J., PAPPU R. V., TOMPA P., UVERSKY V. N., WRIGHT P. E., BABU M. M., 2014. Classification of intrinsically disordered regions and proteins. Chem. Rev. 114, 6589-6631.

VElichKo A. K., MARKova E. N., PETROVA N. V., RAZIN S. V., KANTIDZE O. L., 2013. Mechanisms of heat shock response in mammals. Cell. Mol. Life Sci. 70, 4229-4241.

WAGNER R., 1835. Einige bemerkungen und fragen über das keimbläschen (vesicular germinativa). Müller's Archiv. Anat. Physiol. Wissenschaft Med. 268, 373-377.

WANG K., WANG L., WANG J., Chen S., ShI M., CHENG H., 2018. Intronless mRNAs transit through nuclear speckles to gain export competence. J. Cell Biol. 217, 3912-3929.

Xie S. Q., Martin S., Guillot P. V., Bentley D. L., POMBO A., 2006. Splicing speckles are not reservoirs of RNA polymerase II, but contain an inactive form, phosphorylated on serine 2 residues of the C-terminal domain. Mol. Biol. Cell 17, 1723-1733.

Xing Y., Johnson C. V., Moen P. T., McNeIL J. A., LAWRENCE J. B., 1995. Nonrandom gene organization: structural arrangements of specific pre-mRNA transcription and splicing with SC35 domains. J. Cell Biol. 131, 1635-1647.

ZBOREK A., 1987. Ziarnistości interchromatynowe. Postępy biologii komórki 14, 327-346.

ZENG C., BERGET S. M., 2000. Participation of the C-terminal domain of RNA polymerase II in exon definition during pre-mRNA splicing. Mol. Cell Biol. 20, 8290-8301.

Zhang B., ARun G., MaO Y. S., Lazar Z., Hung G., Bhattacharjee G., Xiao X., Booth C. J., WU J., ZHANG C., SPECTOR D. L., 2012. The IncRNA Malat1 is dispensable for mouse development but its transcription plays a cis-regulatory role in the adult. Cell Rep. 2, 111123.

Zhang Q., Kota K. P., Alam S. G., Nickerson J. A., Dickinson R. B., Lele T. P., 2016. Coordinated Dynamics of RNA Splicing Speckles in the Nucleus. J. Cell Physiol. 231, 1269-1275.

ZHou Z., LuO M. J., STRAESSER K., KatahiRA J., HURT E., REED R., 2000. The protein Aly links pre-messenger-RNA splicing to nuclear export in metazoans. Nature 407, 401-405. 
KOSMOS Vol. 69, 1, 17-35, 2020

\section{ANDRZEJ ANTONI SZCZEPANKIEWICZ}

Laboratory of Molecular and Systemic Neuromorphology, Laboratory of Electron Microscopy, Nencki Institute of Experimental BiologyPAS, 3 Pasteur Str., 02-093 Warszawa, Pracownia Mikroskopii Elektronowej, Instytut Biologii Doświadczalnej

im. M. Nenckiego PAN, Pasteura 3, 02-093 Warszawa, E-mail: a.szczepankiewicz@nencki.edu.pl

\section{NUCLEAR SPECKLES AS MODEL OF NUCLEAR BODIES. NUCLEAR SPECKLES IN THE NERVOUS SYSTEM}

\section{Summary}

The cell nucleus, apart from heterochromatin, i.e. a complex of DNA and histone proteins, contains structures called nuclear bodies. These small, usually circular objects, "suspended" in nucleoplasm, consist of proteins or proteins and non-coding RNA. Currently, several types of such structures are known. This article presents current state of knowledge about the bodies called nuclear speckles or interchromatin granule clusters. Observed for the first time by Roman y Cajal in neurons, but present in all types of cells, they are considered as storage and modification sites for mRNA splicing factors. The latest research presented in this article suggests that their participation in RNA metabolism is more complex. This is also evidenced by reports of the role of nuclear speckles in hereditary diseases caused by repetitions of trinucleotides, including those with neurological effects.

Key words: cell nucleus, mRNA maturation, mRNA metabolism, mRNA splicing, mRNA transport, nuclear bodies, nuclear speckles, transcription 